
I'is 1

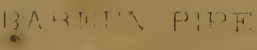
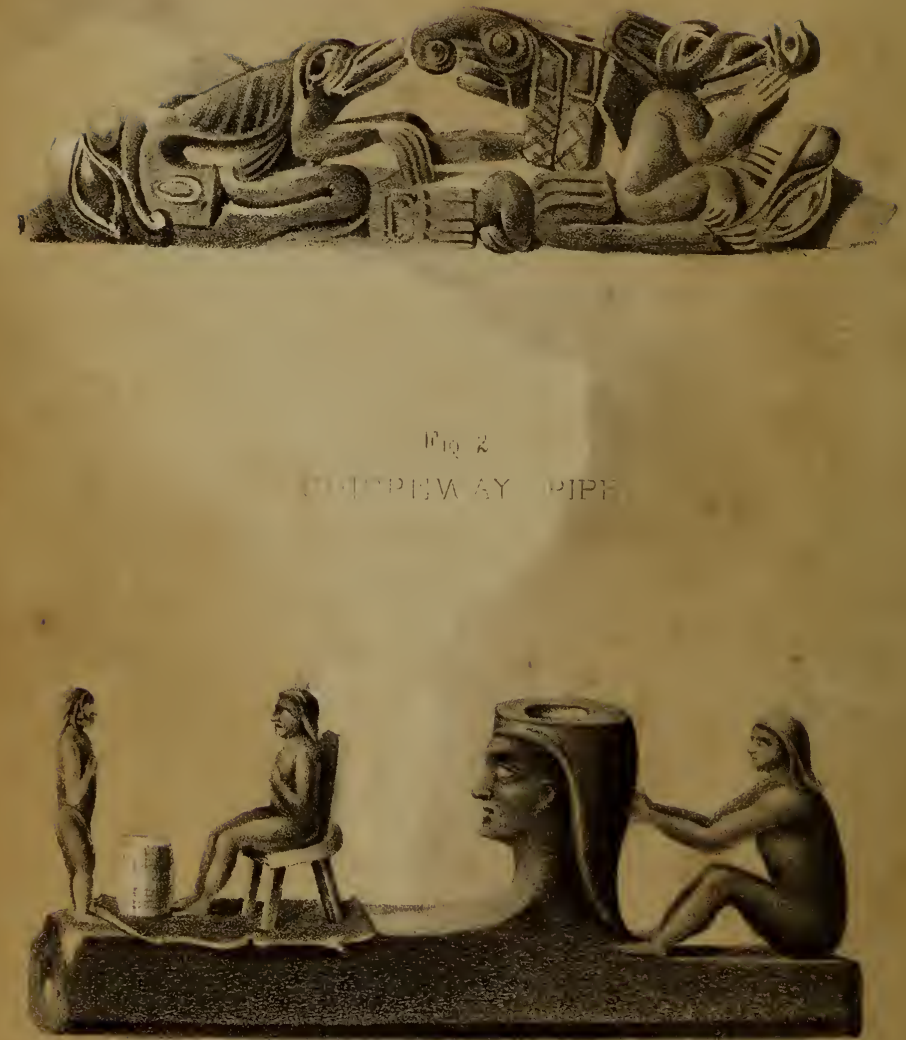


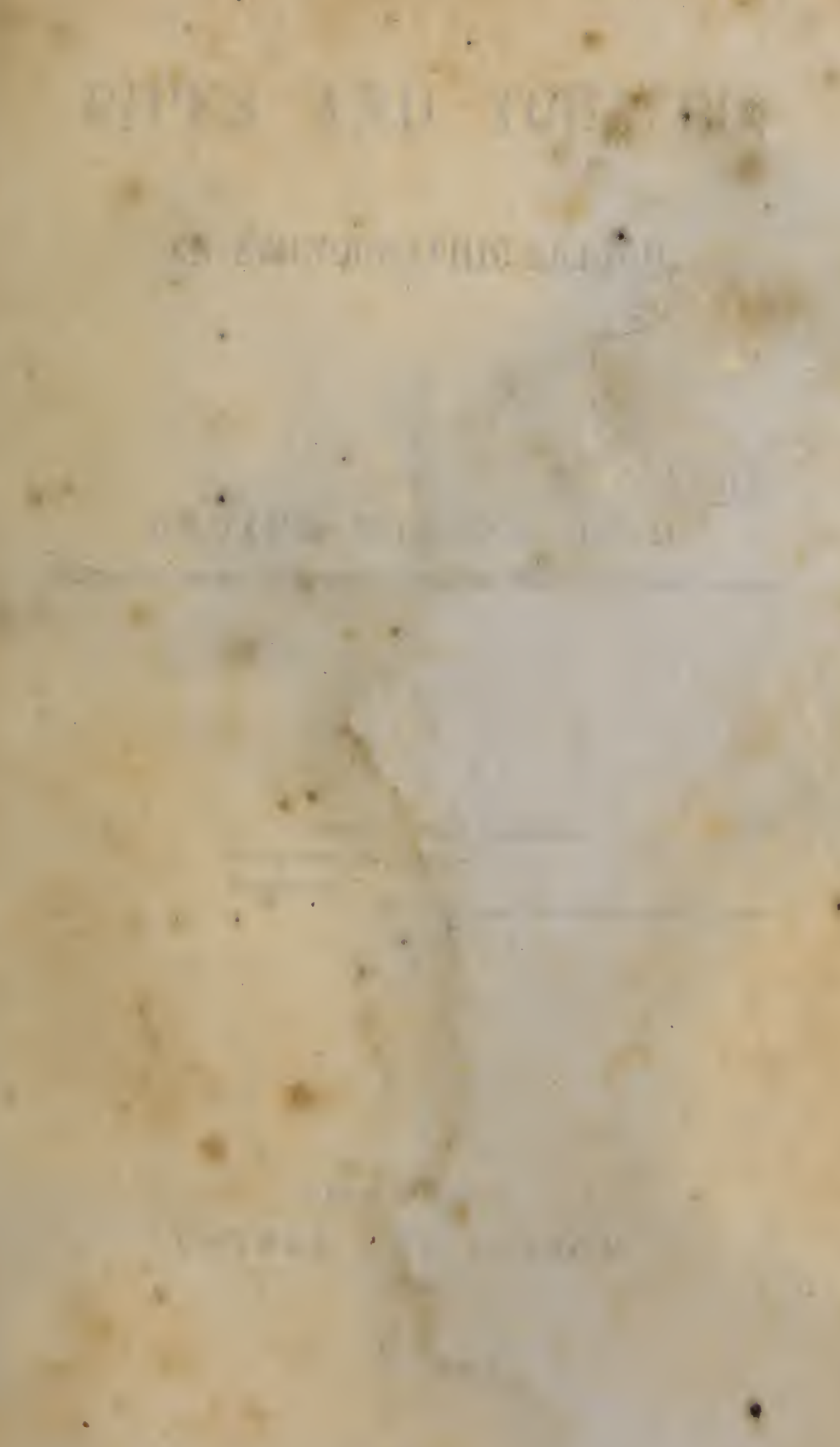





\section{PIPES AND TOBACCO;}

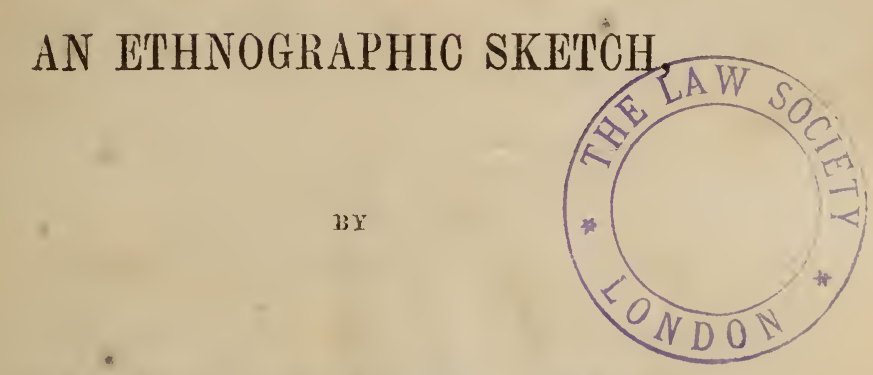

DANIEL WILSON, LL.D.

PROHESFOR OF HISTORY AND ENGLISH LITERATURE, UNIVERSITY COLLEGE, TORONTO.

"Brother of Bacchus, later born,

The old world was sure forlorn,

Wanting thec!"

Charles Laub's Farewell to Tobaceo.

TORONTO:

L O V E L A N D GIB S N .

1857. 
$150 \quad 9006800$ 


\section{TO \\ JOH FENWICK, EsQ., F.S.A.}

ONE OF THE COUNCII OF THIE SOCIETY OF ANTIQUARIES OF NEWCASTLETPON-TYNE, AND COTLESPONDING MEMBER OF TIE SOCIETY

OF ANTIZUARIES OF SCOTJANI):

\section{TH IS BAGA TEL L}

is inscribed in memorial of pleasant licurs spent with him amone

THE ANTEN AND MODERY ROMANS

of

ONS ARLII.

Toronto, Midsummer, 1857. 
i. $\quad$.

,

$=1+$
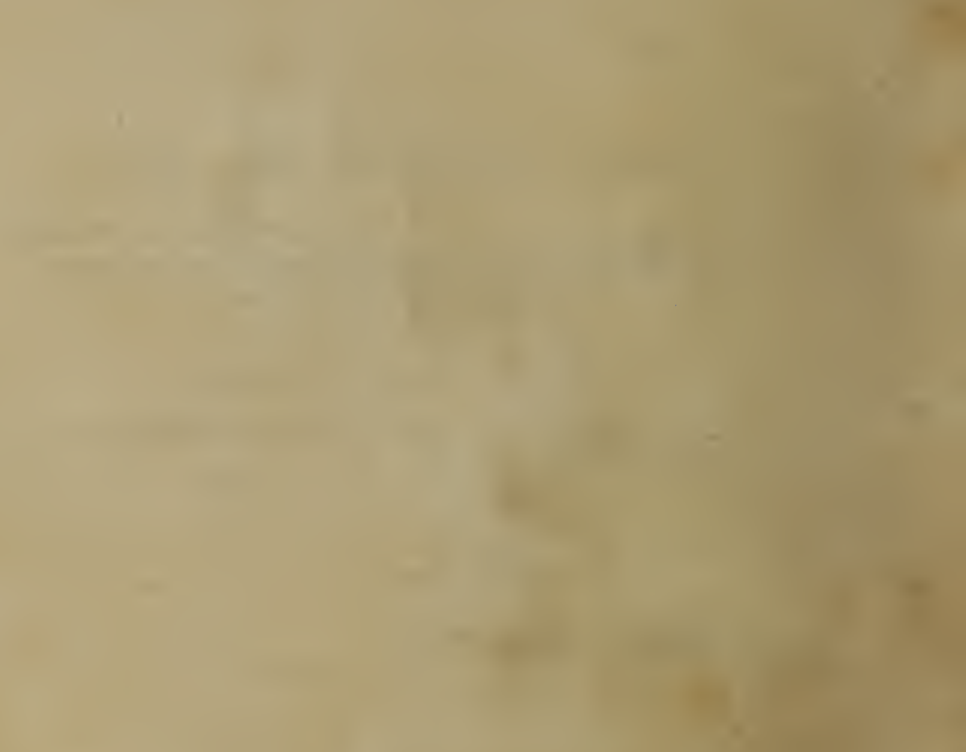

\section{.}
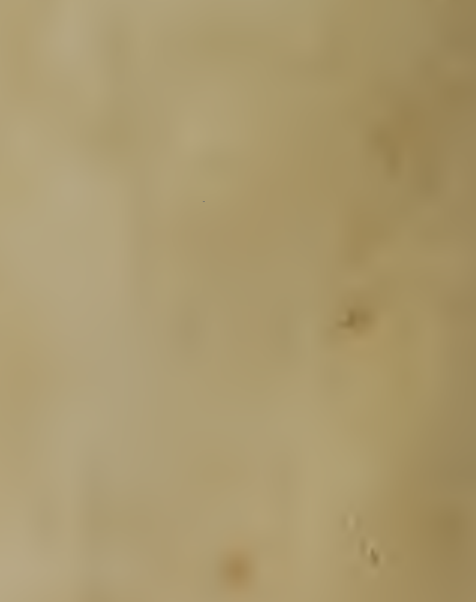


\section{PIPES AND TOBACCO;}

OR, NOTES ON THE

\section{NARCOTIC USAGES AND SUPERSTITIONS}

OF THE

\section{OLD, AND NEW WORLD.}

In attempting to determine the elements on which to base a system of classification of the diverse types or varieties of man, there are frequently one or two prominent characteristics which, alike among ancient and modern races, appear to supply at least convenient tests of classification, while some are deserving of special consideration as indicators of more comprehensive and far-reaching. principles. The ancient epithet "barbarian," had its origin in the" recognition of this idea; and we still apply that of "woad-died" to, the old Briton as the fittest which our knowledge of him supplies: With the Jew and his semitic congeners, the rite of circumcision is a peculiarly distinctive element of isolation, though carried by Islamism, with the Arabic tongue, far beyond their ethnic pale. Brahminism, Buddhism, Parseeism, Sabaism, Fetisism, and even Thuggism, each suffice to supply some elements of classification. The cannibal New Zealander, the large footed Patagonian, the big lipped Babeen, the flat-headed Chinook, the woolly-haired Negro, the clucking Hottentot, and the boomerang-armed Australian, has each his special feature, or peculiar symbol, more or less fitly assigned to him ; and not less, but more distinctly characteristic than any of the se 
are the scalp war-trophy, and the peace-pipe of the American Indian, - the characteristics not of a tribe, or a nation, but of a whole continent. Of the indigenous uniqueness of the former of these there is no question. It may not be altogether unprofitable to reconsider the purely American origin of the usages connected with the latter, on which doubts have been repeatedly cast, and more especially by recent writers, when considering the inquiry from very diverse points of view.

Among the native products of the American continent, there is none which so strikingly distinguishes it as the tobacco plant, and the purposes to which its leaf is applied; for even were it proved that the use of it as a narcotic, and the practise of smoking its burning leaf, had originated independently in the old world, the sacred institution of the peace-pipe must still remain as the peculiar characteristic of the Red Indian of America. Professor Johnston, in his "Chemistry of Common Life," remarks with reference to this and others of the narcotics peculiar to the new world:- "The Aborigines of Central America rolled up the tobacco leaf, and dreamed away their lives in smoky reveries, ages before Columbus was born, or the colonists of Sir. Walter Raleigh brought it within the precincts of the Elizabethean Court. The cocoa leaf, now the comfort and strength of the Peruvian muletero, was chewed as he does it, in far remote times, and among the same mountains, by the Indian natives whose blood he inherits." The former of these narcotics, however, it is scarcely necessary to say, was not confined, within any period known to us, to central America, though its name of tobacco, - derived by some from the Haîtian tambaku, and by others from Talaco, a province of Iucatan, where the Spaniards are affirmed to have first met with it,- appears to have been the native term for the pipe, and not for the plant, which was called kohiba.

So far as we can now infer from the evidence furnished by native arts and relics connected with the use of the tobacco plant, it seems to have been as familiar to most of the ancient tribes of the north west, and the Aborigines of our Canadian forests, as to those of the American tropics, of which the Nicotiana Tabacum is beliered to be a native. No such remarkable depositories indeed have been found to the north of the great chain of lakes, as those disclosed to the explorers of the tumuli of "Mound City," in the Scioto valley, Ohio, from a single one of which,nearly two hundred pipes were taken ; most of them composed of a hard red porphyritic stone, with their bowls elaborately carred in miniature figures of animals, birds, 
reptiles, \&c., executed with great skill and fidelity to nature.* But though not found in such numbers, sufficient examples of this class of relics occur within the Canadian frontier to show the contemporaneous practice of the same arts and customs in this northern region, or to prove such an intercourse with the pipe-sculptors of more southern latitudes, as is assumed in the case of the "Mound Builders," by writers to whom any remote and undefined source ever seems more probable than the une under consideration. Among various examples of such Canadian relics in my own possession are two stone pipe-heads found on the shores of Lake Simcoe. One of these, formed of a dark steatite, though imperfect, exhibits in its carving-a lizard climbing up the bowl of the pipe, with the underside of its lower-jaw ingeniously cut into a human countenance peering over the pipe bowl at the face of the smoker-the same curious imitative art of the native sculptor, as those engraved by Messrs. Squire and Davis, from the aucient mounds of the Mississippi valley. The other is decorated with a human head, marked by broad cheek-bones, and large ears, and wearing a flat and slightly projecting head-dress. The material in which the latter is carved is worthy of notice, as suggestive of its pertaining to the locality where it was found. It is a highly silicious limestone, such as abounds on the shores of the neighbouring Lake Couchiching, and which from its great hardness was little likely to be chosen by the pipe sculptor as the material on which to exercise his artistic skill, unless in such a locality as this, where his choice lay between the hard, but close grained limestone, and the still more intractable crystalline rocks of the same region. Canadian examples of pipesculpture, in a great variety of forms, executed in the favorite and easily wrought red pipe-stone of the Cotcau des Prairies, also occur ; but these are generally supposed to belong to a more recent period, and differ essentially in their style of art from the pipes of the mound builders, worked in granite, porphyry, and limestone, as well as in the steatites, and other varieties of the more easily wrought stones which admit, like the red pipe stone, of the elaborate carving and high degree of finish most frequently aimed at by them. In addition to those, another class of pipes, of ruder workmanship in clay, and oruamented for the most part, only with incised chevron and other conrentional patterns, exhibiting no traces of imitative art, are of frequent occurrence within the Canadian frontiers; and to these I propose to refer more minutely before closing this paper, as objects

*Smithsonian Contributions to Knowledge. Vol. I. p. 152. 
possessing some value in relation to the history of the singular native custom for which such implements were constructed, and to its early practice in Europe. Meanwhile it may be noted that the terms existing in the widely diversified native rocabularies are irreconcileable with the idea of the introduction of tobacco among the northern tribes of the American continent as a recently borrowed novelty. We learn from the narative of Father Francisco Creuxio, that the Jesuit missionaries of the 17 th century, found tobarco in abundant use among the Indians of Canada., So early as 1629 he describes the Huruns as smoking immoderately the dried leaves and stalks of the nicutian plant commonly called tobacco or petune; and such was their addiction to the practice that one of their tribes in Upper Canada, received the designation of the I'etunians, or smokers, from the latter name for the favourite weed.* This term appears to be of Floridian origin, and was perhaps introduced by the missionaries themselves from the southern vocabulary. But the the Chipperay name for tobacco is asainah, seemingly, as Dr. O'Mleara-now, and for many years resident missionary anong the Indians of the Manitouanin Islands,-assures me, a native radical having no other significance or application. So also the Chippeways have the word butta to express smoke, as the smoke of a fire; but for tobacco fumes they employ a distinct term : bucwanay, literally: " it smokes," the puckwana of Longfellow's " Hiawatha." Puahgun is a "tobacco pipe;" and with the peculiar power of compound words and inflection, so remarkable in the languages of tribes so rude as those of the American forests, we have from this root: nipwahguneka: "I make pipes," kipwahguneka: "thou makest pipes," pwahgunea: "he makes pipes, \&c.," so also, nisuggaswa: "1 smoke a pipe," kisuggasua : "thou smokest," suggaswa: "he smokes." While therefore, Europe has borrowed the name of the Indian weed from that portion of the new world first visited by its Genoese discoverer, the language of the great Algonquin nation exhibits an ancient and entirely independent northern vocabulary associated with the use of tobacco, betraying none of the traces of compounded descriptive terms so discernible in all those applied to objects of European

*"Ad insaniam quoque adamant Fumum ex siccatis foliis stirpis snperiore seculo in galliam illatx: (ab eius qui intulit nomine nicotiam placuit appellare: nunc tabacum seu peturum vulgo vocant: atque inde nomen apud Gallos invenit, qux inter Canadenses populos Natio Petuniorum dicitur) eo, quod cerebri exsiccandi vim miram habet, uti per navigationes Europæi consueverant primum, nune vel ab eis vél a Canadensibus res translata ad crapulam. Hi certe ne passum quidem progrediantur sine tnbo longiusculo, quo ejusmodi fumos hauriunt, ac fere ad temulentiam; pertentant enim cerebrum, ebrictatemque demum inducunt, vini instar." "Historice Canadensis, seu Novce Francice." Paris : 1664. Page 76. 
origin. The practice of smoking narcotics, is interworen with all their habits, so that they eren reckon time by pipes, using such word sentences as ningopwahgun, "I was one pipe [of time] about it".

In the Old World most of the ideas connected with the tobacco pipe are homely and prosaic enough: and though we associate the chibouk with the poetical reveries of the oriental day-dreamer, and the hookah with the pleasant fancies of the Angio-Indian reposing in the shade of his bungaloose: nevertheless, the tobacco pipe constitutes the peculiar and most characteristic symbol of America, intimately interwoven with the rites and superstitions, and with the relics of ancient customs aud historical traditions of the Aborigines of this New World. If Europe borrowed from it the first knowledge of its prized narcotic, the gitt was received unaccompanied by any of the sacred or peculiar virtues which the Red Indian still attaches to it as the symbol of hospitality and amicable intercourse ; and Longfellow, accordingly, with no less poetic vigor, than fitness, opens his "Song of Hiawatha" with the institution of "the peacepipe," by the Great Spirit, the master of life. With all the unpoetical associations which are inseparable from the modern uses of the nicotian weed, it required the inspiration of true poetry to redeem it from its base ideal. But this the American poet has accomplished fully, and with the boldest figures. The Master of Life descends on the mountains of the Praiiie, breaks a fragment from the red stone of the quarry, and fashioning it with curious art into a figured pipe-head, he fills it with the bark of the red willow, chafes the forest into flame with the tempest of his breath, and kindling it:

Erect upon the mountains

Gitche Iranito, the mighty,

Smoked the calumet, the peace-pipe,

As a signal to the nations.

And the smoke rose slowly, slowly,

Through the tranquil air of morning,

First a single line of darkness,

Then a denser, bluer vapor,

Then a snow-white cloud unfolding,

Like the tree tops of the forest,

Ever rising, rising, rising,

Till it touched the top of hearen,

Till it broke against the beaven

And rolled onward all arouud it.

And the tribes of the ancient Aborigines gathering from rirer, lake, and prairie, assemble at the divine summons, listen to the warnings and promises with which the Great Spirit seeks to guide them; 
and this done, and the warriors having buried their war clubs, they smoke their first peace-pipe, and depart :

While the Master of Life, ascending,
Through the opening of cloud-curtains,
'Through the doorways of the heaven,
Vanished from before their faces,
In the smoke that rolled around him,
The pukwana of the perce pipe!

It is no mean triumph of the poet thus to redeem from associations, not only prosaic, but even offensive, a custom which so peculiarily pertains to the usages and the rites of this continent from the remotest times of which its historic memorials furnish any trace; and which was no sooner practically introduced to the knowledge of the old world, than that royal pedant, king James, directed against it his world-famous "Counterblast to Tobacco," describing its use as "a custom loathesome to the eye, hateful to the nose, harmful to the brain, dangerous to the lungs, and in the black stinking fume thereof, nearest resembling the horrible stygiau smoke of the pit that is bottomless!"'

The history of the custom thus dignified by the assaults of rovalty, and against certain uses of which the supreme pontiff, Urban, VIII., fulmiuated the thunders of the church, has attracted considerable attention in modern times on various grounds. In their relations to physiology the use and effects of narcotics claim an important consideration; and the almost universal diffusion of tobacco in modern times, accompanied with its peculiar mode of enjoyment, so generally adopted by the most diverse tribes and nations in every quarter of the globe, give its history a preeminence in any such inquiry. The questions as to whether the practice of smoking narcotics, or even the use and peculiar properties of tobacco, were known to the old world prior to the discovery of America, have accordingly repeatedly excited discusssion; though it has not been always remembered that the inquiry as to the indigenous character of certain varieties of the tobacco plant in the old world, and even as to the use of such a narcotic, involve questions quite distinct from that of the origin of the very peculiar mode of partaking of the exhilerating or intoxicating effects of various narcotics by inhaling their burning fumes through a pipe.

The green tobacco, nicotiana rustica, cultivated in Thibet, western China, northern India, and Syria, is a different species from the American plant; and while it is affirmed by some to have been 
brought from America, and even the precise date of 1570, is assigned for its importation into Britain, high authorities in Botany are still found to maintain the indigenous character of the nicotiana rustica, in some parts of the old world, as in northern India, where it is stated to grow wild. DuWalde, $(1793$,$) speaks of tobacco as one of$ the natural productions of Formosa, whence it was largely imported by the Chinese; and savary, O iearius, Chardin, and other writers, are ail quoted* to show that the nicotiana Persica, which furnishes the famous shiraz tobacco, is not only indigenous to Persia, (an opinion favoured by high authorities in botany,) but that it was used for smoking from very early times. That all the varieties of the Nicotiana are not cunfined to the new world is unquestionable. Of some fifty-eight admitted species, the great majority are indeed American, but a few belong to the newer world of Australia, besides those believed to be indigenous to Asia. It is not surprising therefore, that after all the attention which this subject has latterly, on various accounts, attracted, writers should be found to maintain the opinion that the use of tobacco as a narcotic was known and practised by the Asiatics, prior to the discovery of America. The oriental use of tobacco may indeed be carried back to an era old enough to satisfy the keenest stickler for the antiquity of the practice, if he is not too nice as to his authorities. Dr. Yates in his Travels in Egypt, describes a painting which he saw on one of the tombs at Thebes, containing the representation of a smoking party. But this is modern compared with a record said to exist in the works of the early fathers, and, at any rate, preserved as an old tradition of the Greek Church, which ascribes the inebriation of the patriarch Noah to the temptation of the Devil by means of tobacco; so that King James was not, after al!, without authority fur the black stygian parentage he assigns to its fumes! Professor Johnston-who marshalls various authorities on the Asiatic use of tobaceo for smoking, prior to the discovery of America, without venturing on any very definite opinion of his own,- quotes Pallas as arguing in favour of the antiquity of the practice from its extensive prevalence in Asia, and especially in Chiıa. "Amongst the Chinese," says this writer, "and among the Mongol tribes who had the most intercourse with them, the custom of smoking is so general, so frequent, and has become so indispensable a luxury; the tobacco-purse afixed to their belt so necessary an article of dress; the form of the pipes, from which the Dutch seem to have taken the model of theirs, so original;

*A. C. M. Exeter. Notes and Queries. Vol. II. p. 154. 
and lastly, the preparation of the yellow leaves, which are merely rubbed to pieces, and then put into the pipe, so peculiar, that they could not possibly derive all this from America by way of Europe, especially as India, where the practice is not so general, intervenes between Persia and China." But the opinions of Dr. Meyen, formerly Professor of Botany in the University of Berlin, are worthy of still greater weight, set forth as they are, alike on Archælogical and Botanical grounds. In his "Grundriss der Pflanzengeogruphie," or "Outlines of the Geography of Plants," recently translated for the Ray Society, he observes: "It has long becn the opinion, that the use of tobacco, as well as its culture, was peculiar to the people of America, but this is now proved to be incorrect by our present more exact acquaintance with China and India The consumption of tobacco in the Chinese empire is of immense extent, and the practice seems to be of great antiquity, for on very old sculptures I have observed the very same tobacco pipes which are still used. Besides we now know the plant which furnishes the Chinese tubaceo, it is even said to grow wild in the East Indies. It is certain that this tobacco plant of eastern Asia is quite different from the American species. The genus Nicotiana, generally speaking, belongs to the warmer zones, yet a few species of it have a very extensive area, and a great power of resisting the influence of climate, for they can be grown under the equator, and in the temperate zone, even far above $55^{\circ}$ north latitude, where the mean summer heat is equal to $15.87^{\circ} \mathrm{Cels}$. 'The southern polar limit for the culture of tubacco is not exactly known, but it seems to extend to the 40th degree of latitude, for in south America tobacco is cultivated at Conception, and in New Zealand enough is grown for the consumption there."*

To India, then, Dr. Meyen inclines. with others, to refer the native habitat of an Asiatic tobacco, which he thus affirms to have been in use by the Chinese as a narcotic, and consumed by inhaling its smoke through a pipe, altogether independent of the introduction of this luxury to Europe by the discoverers of America in the fifteenth century. While the Turk still chews the opium in which he so freely indulges, the Chinese, and also the Mialays smoke it, most frequently using as a pipe a bamboo, which serv's also for a walking stick, and requires a very slight operation to convert it into an opium pipe. The Chinese opium smoker secur es the utmost effects of that powerful narcotic by swallowing the snoke; and notwithstanding this mode of using the narcutic derived from the poppy is

* Meyen's Outlines of the Geography of Plants. Ray Society. Page 361. 
acknowledged to be of comparatively recent introduction, when we call to remembrance that that strange people preceder Etrope in wood engraving, printing, the compass, and others of the most important of modern discoveries, there would be no just cause of surprise should it be proved that to then also we must ascribe such merit as pertains to the initiative in the us's to which tobaceo is applied. Such evidence, however, must not be too hastily aceepted; for a profoundly scientific botanist, thougl, an altogether trustworthy au'hority in relation to the habitat of the plant, may be very little qualified to pronounce an opinion on the value of such Chinese monumental evidence as $\mathrm{Dr}$. Meyen loosely refers to under the designation of "very old sculptures."

The Koran has been appealed to, and its modem versions even furnish the $\Delta$ merican name. A traditional prophecy of Mahomet is also quoted by sale, which while it contradicts the ass!n rsed existence of tobacco in his time, foretells that: "in the latter days there shill be men bearing the name of moslem. but not really such, and they shall smoke a certain weed which shall be ealled tobaceo!"** If the prophecy did rot bear on the face of it such unmistakeable evidence of being the invention of sone moslem ascetic of later times, it would furnish no bad proof of Mahomet's right to the title of "the false prophet," for Sale quotes in the same preliminary discourse to his edition of the Koran, the l'ersian proverb "coffee without tobacco is meat without salt." An appeal to the graphic pictures of eastern social habits in the "Arabian Nights' Entrotainnents," furnishes strong evidence against the arcient knowledge of a custom now so universal; and in so far as such negative evidence may be esteemed of any value, the pages of our own Shakespeare seem equally conclusive, though, as will be seen, the practice had not only been introduced into England, but was becoming faniliarily known before his death.

The "drinking tobacco," as smoking was at first termed, from the mode of partaking of its fumes then practiced, finds apt illustration in the language of our great dramatist. The poet, in "Timon," speaks of the sycophantish followers of the noble Athenian "through him drinking free air ;" in the "Tempest" Ariel, eager in her master's service, exclaims: "I drink the air before me," and in "Antony and Cleopatra," the Egrptian Queen thus wrathfully pictures the indignities of a Roman triumph :- 
"Mechanic slaves

With greasy aprons, rules, and hammers shall Uplift us to the view; in their thick breaths, Rank of gross diet, shall we be enclouded, And forced to drink their vapour."

The references to drinking usages, moreover, are scattered plentifully through all his dramas, and intensified by the most homely and familiar illustrations, but without a single reference indicative of smoking usages; though various passages occur strikingly suggestive of such allusions, had the practice been as familiar as it became in those of younger contemporaries who survived him. In "Much Ado About Nothing," Borachio tells Don John: "being entertained for a perfumer, as I was smoking a musty room, comes in the Prince and Claudio hand in hand, in sad conference." (Act I. Scene III.) Again in "Komeo and Juliet," Rumeo thus speaks of brawling luve :-

" $O$ anytiing. of nothing first created!

$O$ heavy lightness! Serious vanity!

Mis-shapen chaos of well seeming furms!

Feather of lead, bright sinoke, cold fire, sick health !"

And again in the same scene he exclaims:-

"Luve is a smoke made with the fume of sighs."

If, as Malone infers from a satire of Sir John Davis, and other early notices, tobaceo was smoked by the wits and gallants on the English stage, before the close of the sixteenth century, it is difficult to evade the conclusion that such similes may have derived their force from the tobaceo fumes which rose visibly in sight of the audience. 'These allusions and similes, however, have perhaps more resemblance in rerbal form, than in embodied fancy, to the ideas now suggested; and may be deemed, after all, sufficiently independent of the smoker's "cloud" to involve no necessary association with it, even had such been faniliar to the poet; but it seems to me scarcely possible that Shakespeare could have retained unmodified the language of Lady Mac:beth, in the conclusion of the first act of " Macbeth," - one of the productions of his later years, - had the fumes of tobacco been so associated with wine and wassail, as they were within a very few years after the date of that wonderful drama. Encouraging her busband to "screw his courage to the sticking place," she says :-

"His two chamberlains

Will I with wine and wassail so convince,

That memory, the warder of the biain,

Shall be a fume, and the receipt of reason

A limbeck ouly." 
It may be, indeed, that the recently acquired knowledge of tobacco and its fumes, in Europe, sufficed to prerent the poet introducing such an anachronism amid scenes of ancient Scottish story. Nevertheless, a hypercritical adherence to archæological proprieties never interferes with the graphic touches which give life to every scene of the Shakespearean drama ; and that the mere anachronism would not of itself have deterred Shakespeare from an allusion to tobacco, if its unfamiliar novelty did not render it unsuitable for his purpose, may be inferred frcm liberties of a like kind which have proved fertile texts to many a verbal critic. The soldier's simile in the same tragedy, (Act I., Scene II.,) where he compares the royal captains, Macbeth and Banquo, to "cannons overcharged with double cracks ;" or Sweno of Norway, disbursing his ten thousand dollars at Saint Colmes Inch; (Act I., Scene III.,) or Menenius, in "Coriolauus," (Act $\mathrm{V}$., Scene I..) with his :-

"Pair of tribunes that have rack'd for Rome

To make coals cheap;"

or a hundred similar instances, familiar to the readers of our great dramatist, would all seem equally inadmissible were they not already there. It seems to me, huwever, that the assuciation of tobacco "fumes" with "wine and wassail," a very few years later than the production of " Nacbeth," would have prevented the use of the former term, in such an association in its less popular sense, as is done in that drama. The allusion there is to the rising of fumes of vapour, in distillation; but Bacon, who, in his thirty-third essay : "Of L'lantations," speaks of the tobacco of Virginia as one of the "commodities which the soil where the plantation is, doth naturally yield," elsewhere recommends " that it were good to try tise taking of fumes by pipes, as they do in tobacco, of other things to dry and comfort." Here therefore, we perceive the adoption of Shakespear's term "fumes," for the smoke of tobacco within a very few years after the production of "Macbeth," a work assigned by nearly all his best editors to the reign of James I.

It is curious indeed to note how nearly we can approximate to a precise date for the literary recognition of the "Indian weed," which has been such a farourite of the student in later times. Warner, who wrote his once popular "Albion's England," in 1586, added to it three additional books in 1606, in the first of which (Book XIV. chap. 91.), a critical imp inveighs against the decline of the manner's of the good old times; and anong other symptoms of decay, misses the smoke of the old manor-chimney, which once gave evidence of 
the hospitable hearth within. But, in lieu of this he notes a more perplexing smoke which "proceeds from nostrils and from throats of ladies, lords, and silly grooms," and exclaims astonished :-

"Great Belzabub ! can all spit fire as well as thine?"

But his fellow Incubus allays his fears by telling him that this novelty :-

"Was an Indian weed,

That fumed away more wealth than would a matuy thou:ands feell."

Tobacco, therefore, was not only in use, but already indulged in to an extravagant excess, in shakespeare's later years. Though unnamed in his works, it repeatedly occurs in those of Decker, Middleton, and others of the early minor dramatists; and still more fal: iliarily in those of Ben Jonson, Beaumont and Fletcher, and others of later date. In Middleton's "Roaring Girl," produced in 1611, five years before the death of Shakespeaer, and peculiarly valuable from the lively. though sufficiently coarse picture it furnishes of London manners in his day, we learn that "a pipe of smoak" was to be purchased for sixpence. In Ben Jonson's "Alchemist," of the same date, "Drugger, the tobacco man," plays a part; and a similar character figures among the dramatis persone of Beaumont and Fletcher"s "Scornful Lady." Moreorer, the earliest of these notices not only refers to the costliness of the luxurious weed, with a pipe of which. Drugger bribes the Alchemist; but the allusions are no less distinct to the adulteratious practised even at so carly a date, and which were no doubt hinted at by Jonson in the name of his tobacconist. "Doctor" exclaims Face, the servitor, to subtle the Alchemist, when introducing $\mathrm{Abel}$ Drugger to his farourable notice, (Act. I., Scene I. ):-

\section{"Doctor, do you hear!}

This is my friend Abel, an honest fellow;

He lets me have good tobaccu, and he does not

Suphisticate it with sack-lees or oil,

Nor washes it in muceadel and grains,

Nor buries it in gravel under ground,

Wrepp'd up in greasy leatler, or piss'd clouts,

But keeps it in fine lily pots, that operid

Smell like conserves of roses, or French bears."

It is obvious liere that, even thus early, Hen Jonson's allusions to the favourite "weed" are not to an unfamiliar novelty ; though both with him, and in the later works of Beaunont and Fletcher, it is referred to invariably as a costly luxury. "Tis' good tobaceo, this!" exclains Subtle; "what is't an ounce?" and Saril, the steward, in 
"The Scornful Lady" speaks ironically of "wealthy tobacco-merchants, that set up with one ounce, and break for three!" It shares indeed, with gambling, drinking, and other vices, in helping on the joung spendthrifts of the drama to speedy ruin. In "Bartholomew Fair," (Act II., Scene VI,) the puritan Justice, Overdo, warns against "lusting after that tawny weed tobacco, whose complexion is like the Indian's that vents it!" and after berating it in terms scarcely quotable, he reckons the novice's outlay at "thirty pounds a week in bottle-ale, forty in tobacco!" So, too, in Beaumont and Fletcher's "Wit without Money," Valentine "a gallant that will not be persuaded to keep his estate," picturing to his faithless rivals in his love suit. the beggary that awaits them, sums up a list of the slights of fortune with: "English tobacco, with half-pipes, nor in halt a rear once burnt." More quaint is the allusion with which Robin Goodfellow, in "the Shepherd's 1)ream." (1612.) fixes the introduction of the novel luxury, where reluctantly admitting the benefits of the Reformation, he bewails the exit of popery and the introduction of tobacco as concurrent events!

From this date the allusions to the use and abuse of the Indian weed abuund, and leare no room to question the wide diffusion of the practice of smoking in the serenteenth century. Burton, in his "Anatomy of Melancholy," (1621), prescribes tobacco as "a sovereign remedy to all diseases, but one commonly abused by most men ;" while in Zacharie Boỵd's "Last Battcll of the Soule in Death," printed at Edinburgh in 1629, the quaint old divine speaks of the backslider as one with whom "the wyne pint and tobacca pype with sneesing pouder, provoking sneuele, were his heartes delight!"

The term employed by Zacharie Boyd for snuff, is still in the abreviated form of "sneeshin" the popular Scottish name for this preparation of tobacco. There are not wanting, however, abundant proofis of the ancient use of aromatic powders as snuff, long before the introduction of tobacco to Europe. One familiar passage from Shakespeare will occur to all; where Hotspur describing the fopling lord "perfumed like a milliner," adds :-

"And 'twixt his finger and his thumb he held

A pouncet-box, which ever and anon

He gave his nose, and took't away again;

Who, therewith angry, when it next came there

Took it in snuff."

The illustration which this passage affords of the ancient use of pungent and aromatic powders in one manner in which tobacco has been so extensively employed since its introduction into Europe, 
adds greatly to the force of the argument against any older employment of narcotics in the way of inhaiing their fumes, based on the absence of eariier notices of so remarkable a custom. The use indeed of various narcotics, such as opium, bang: the leaf of the hemp plant, and the betel-nut, the fruit of the Areca palm, by the southeastern A siatics appears to be traceable to a remote antiquity. Northern Europe has, in like mauner, had its ledum and hop, and in Siber ia, its amanita muscaria, or narcotic fungus. But the evidence fails us which should prove that in the case of the pipe, as in that of the pouncet-box, the tobacco only came as a substitute for older aromatics, or narcotics similarily employed. Nor when the evidence is looked into more carefully, are such direct proofs wanting, as suggest a comparatively recent origin, in so far as both Europe and Asia are concerned, to the peculiar mode of enjoying such narcotics by inhaling their fumes through a pipe attached to the bowl in which they are subjected to a slow process of combustion.

When engaged, some years since, in the preparation of a work on Scottish Archæology, my attention was directed, among various minor antiquities of the British Islands, to a curious class of relics popularly known in Scotland by the name of Celtic or Eifin pipes, in the north of England as Fairy pipes, and in Ireland where they are more abundant, as Danes' pipes. 'These are formed of white clay, with some resemblance to the form of the modern clay pipe, but variously ornamented, and invariably of a very small size compared with any tobacco-pipe in modern use. Similar relics have since been observed in England, found under circumstances calculated, like those attending the discovery of some of the Scottish examples to suggest an antiquity for them long anterior to the introduction of Anerica's favourite narcotic, with what King James, on finding its taxability, learned to designate its "precious stink!' The most remarkable of such discoveries are those in which pipes of this primitive form have been found on Roman sites along side of genuine Roman remains. Such was the case, on the exposure, in 1852, of part of the ancient Roman wall of London, at the Tower postern ; and, along with masonry and tiles, of undoubted Roman workmanship, a mutilated sepulchral inscription was found possessed of peculiar interest from supplying the only example, so far as I am aware, in Britain, of a Christian date of the second century :-

$$
\mathrm{PO} \mathrm{ANNO}+\mathrm{C} \text { LXX* }
$$

In the summer of 1853 , only a few months after this London dis-

- M.S. Letter J. W. Archer, Esq., London, April, 1853. 
covery of "Fairy Pipes" along with Anglo-Roman remains of the second century, similar discoveries were made on the site of the Roman Town of Bremenium, and at one of the Forts on the wall of Hadrian, in Northumberland. The learned author of "The Roman Wall," thus refers to the discovery in the second edition of that work.* "Shall we enumerate sinoking pipes, such as those shewn in the cut, [which precisely correspond to many similar examples of the smallest size of the so called Fairy or Danes' Pipes,] among the articles belonging to the Roman period? Some of them inảeed, have a medieval aspect; but the fact of their being frequently found in Roman stations, along with the pottery and other remains, undoubtedly Roman, ought not to be overlooked." After some further remarks in detail, Dr. Bruce proceeds to quote the following passage from the "Prehistoric Annals of Scotland:" -

"Another class of relics found in considerable numbers in North Berwick, as well as in various other districts, are small tobacco-pipes, popularly known in Scotland by the names of Celtic or Elfin pipes, and in Ireland, where ther are even more abundant, as Danes' pires. To what period these curious relics telong I am at a loss to determine. The popular names attached to them, manifestly point to an era long prior to that of Sir Walter Raleigh and the maiden queen, or of the royal author of 'A Counterblast to Tobacco,' and the objects along with which they hilve been discovered, would also seem occasionally to lead to similar conclusions, in which case we shall be forced to assume that the American weed was only introduced as a superior substitute for older narcotics. Hemp may, in all probability, have formed one of these ; it is still largely used in the east for tbis purpose."

When preparing the notices of miscellaneous minor Scottish antiquities, from which the above passage is abstracted, my attention had been directed, for the first time, to these relics of the old smokers' nicotian indulgences. 'The discovery of miniature pipes, under peculiar circuinstances, har been noted in the Statistical Accounts and elsewhere, from time to time; but so far as I am aware, they had not been subjected to special notice or investigation by any previous Scottish antiquary ; and finding evidence, then quoted + - of the discovery of the miniature Elfin Pipe, in "Jritish encampments ;" in the vicinity of a primitive monolithic monument, with flint arrow heads, stone celts, \&c.; in an ancient cemetery, alongside of medieval pottery, at North Berwick; and at,considerable depths in various loealities; as for example, six feet in a moss between Scalloway and

* The Roman Wall, an historical and topographical description of the Barrier of the Lower Isthmus, extending from the Tyne to the Solway; by the Rev. J. C. Bruce, M. $\mathbf{A}$ Sccond Edition, 1853, p. 411.

† Archxology and Prehistoric Annals of Scotland, 1S51, p. 680. 
Lerwick, in the Orkncys; I remarked in reference to such notices that some of them were certainly suggestive of the little Elfin pipes belonging to a remote era. When, however, my esteemed friend Dr. Bruce, quoted me in seeming confirmation of, at least the possibility that the old Roman Legionary of Hadrian or Severus occasionally solaced himself with a pipe, as he kept watch and ward on the ancient barrier which in the first centuries of our era marked the outer verge of the Roman world, he took from the page just as much as sufficed to give a delicate flavor of possibility to the fancy, so pleasant to the mind of a genuine devotee of the luxurious weed, that the tobacco-pipe is a classic institution!

I doubt not but the learned Roman Antiquary of Pons Elii, in his zeal to provide the Tungrian Legionaries of old Borcovicus, or the Spanish Varduli of Bremenium, with the consolations of a pipe, to beguile th ir dreary outlook from that bleak Northumbrian outpost of Imperial civilzation, most honestly and unwitringly overlouked whatever failed to square with the manifest fitness of so pleasant a conceit; nor disl it ever occur to me to think of putting the old Tungrians' pipe out, by continuing the quotation, until now when, in the tardy access to British periodicals, I find myself quoted as an authority for the antiquity of the tobacco-pipe,-not only by those who, farouring such an opiniun, are willing to count even the most lukewarm adherent on their side, but by others who treat me as Oliver Proudfoot, the bonnet maker, did his wooden soldan, which he set up merely for the pleasure of knocking it down; or as the gallant Bailie and bomnt maker of Saint Johnstoune salys: "Marry, and sometimes I will place you a bonnet (:1n old one most likely, ) on my soldau's head, and cleave it with such a downright blow, that in troth, the infidel has but little of his skull remaining to hit at!" Far be it from me to interfere with the practice of those who, like the valiant bomnet maker, wish to make themselves familiar with the use of their wrapon on such easy terms, even though, perforee, made the wooden soldan on which it is applied; but I must confess to a decided objection to being held responsible for opinions quoted only for the purpose of refutation, when as it would seem, these are read through such a refracting medium as the Roman spectacles of an antiquary, who may be assumed without any disparagement to be a little wall-eyed.

Quotations at second hand are never very trustwortlyy, and it seems difficult to credit with more direct knowledge than such as may be derived from the partial quotation in the "Roman Wall," such 


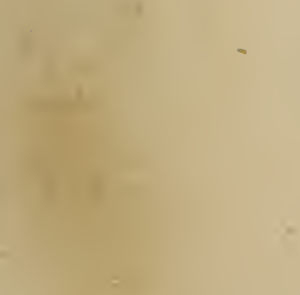




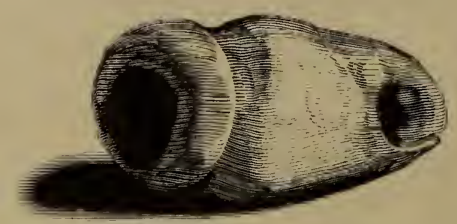

FıG. 1. Stone Pipe, Morningside.

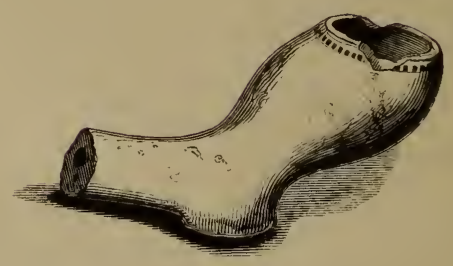

Frg. 2. Clay Pipe, North Berwick. 



II

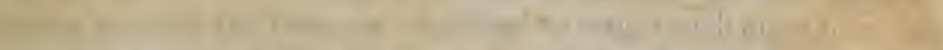

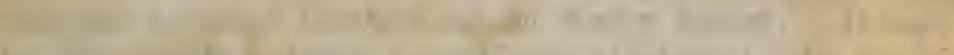

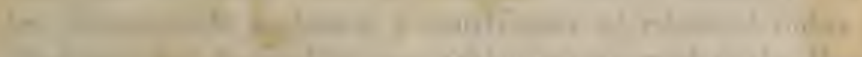

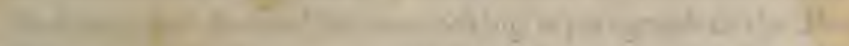

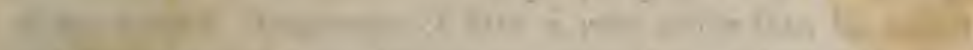

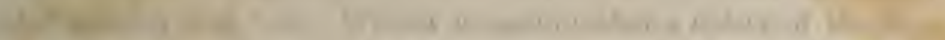

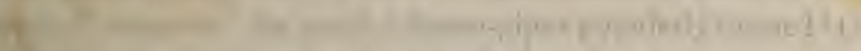
(T) T

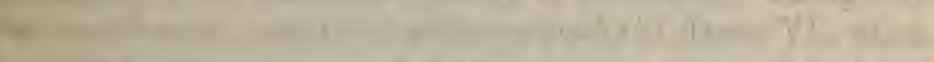

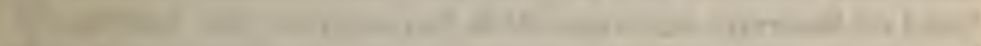

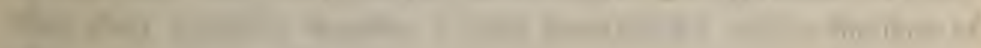
$\sqrt{2}$

$-2$

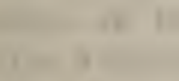

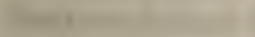

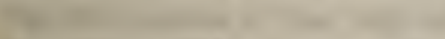

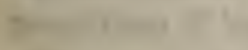

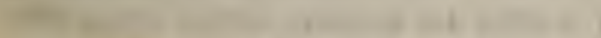
t

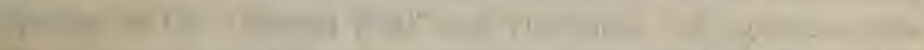
I

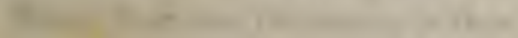

4

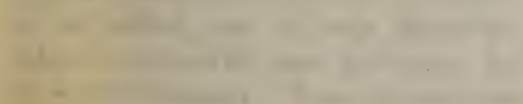

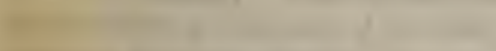

$\sqrt{2}$

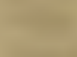

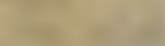

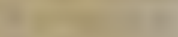

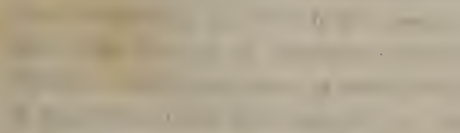

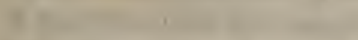



writers as one in the Archaological Journal,* who, after referring to Mr. Crofton Croker's signal refutation of "this absurd notion," couples me with Dr. Bruce as "inclined to assign such pipes to an age long prior to that of Elizabeth and Sir Walter Raleigh." It might be unreasonable to blame a contributor of editorial notes to the Archceological Journal for overlooking a paragraph in the Proceedings of the Scottish Antiquaries, of date a year earlier than his note, $\uparrow$ which records that "Dr. Wilson communicated a notice of the discovery of various of the small tobacco-pipes popularly termed 'Celtic' or 'Elfin pipes,' in digging the foundation of a new school house at Bonnington, in the immediate vicinity of Edinburgh. Along with these were found a quantity of bodles or placks of James VI., which he exhibited with the pipes, and at the same time expressed his belief that they probably supplied a very trustworthy clue to the date of this somewhat curious class of minor antiquities." This more matured opinion of 1853 lay out of the way, and might not be noticed by the Archæological Journalist, as it would assuredly have been overlooked by the zealous Roman, quite as much as the following continuation of the original quotation so aptly abridged to the proportions of his classic tunic. But any writer wholooked in its own pages, for the opinions set forth on this subject, in the "Prehistoric Annals of Scctland," would have found that the abbreviated quotations in the "Roman Wall" and elsewhere, only give one side of the statement, and that, after referring to an article in the Dublin Penny Magazine, the inquiry is thus summed up :-

"The conclusion arrived at by the writer in that magazine is, that these Danes" pipes are neither more nor less than tobacco pipes, the smallest of them pertaining to the earliest years of Queen Elizabeth's reign, when the rarity and value of tobacco rendered the most diminutive howl sufficiently ample for the enjoyment of so costly a luxury. From this he traces them down to the reign of Chirles II. by the increasing dimensions of the bowl. It is not improbable that these conclusions may be correct, notwithstanding the apparent indications of a much earlier origin, which circumstances attendant on their occasional discovery have seemed to suggest.

The following description of a curious Scottish memorial of the luxury would, however, seem at least to prove that we must trace the introduction of tobacco into this country to a date much nearer the discovery of the new world by Columbus than the era of Raleigh's colonization of Virginia. The grim old keep of Cawdor Castle, associated in defiance of chronology with King Duncan and Macbeth. is augmented like the majority of such Scottish fortalices, by additions of the sixteenth century. In one of the apartments of this latter erection, is a stone

* Archæological Journal, Vol. XI., p. 182.

† Proceedings S. A. Scot. Vol. I. p. 182. 
chimney, riehly carved with armorial bearings and the grotesque deviees common on works of the period. Among these are a mermaid playing the harp, a monkey blowing a horn, a eat playing a fiddle, and a fox smoking a tobacco pipe. There can be no mistake as to the meaning of the last lively representation, and on the same stone is the date 1510, the yeur in whieh the wing of the castle is ascertained to have been built,"* and in which it may be added, Janaica was settled by the Spaniards.

Having thus even at the very first,-while " at a loss to determine to what period the curious relics called Dane's or Elfin pipes belonged," and consequently avoiding a dogmatic assertion on a subject "left for further investigation," - furnished a tolerably significant indication of my inclination to assign to such nicotian relics a postColumbian introduction to Britain; and having, moreover, at a later period given unequivocal expression of a coufirmed opinion of their modern origin: I was somewhat surprised to find myself, not very long since, figuring alongside of a singularly creditable array of chivalrous archæologists, all knights of the ancient tobacco pipe, and ready to shiver a lance with any puny modern heretic who ventured to question that Julius Cæsar smoked his merchaum at the passage of the Rhine, or that Herodotus partook of a scythian peace-pipe when gathering the materials for the birth of History! Here is the array of leurned authorities, clipped out of a recent English periodical, produced as it will be seen, to answer in the affirmative, that the ancients did smoke: Scythian and Roman, Celt, Frank, and Norman !

DiD the Ancienrs Smoke? - The question as to whether smoking was known to the ancients has just been started in Germany by the publication of a drawing contrined in the Recueil des Antiquités Suisses of Baron de Bonstetten, which represents two objeets in elay, which the anthor expressly declares to be smuking pipes. The authors of the "History of the Canton of the Grisons" had already spoken of these objects, but elassified them anong the instruments made use of by the suothsayers. The Abbé Cochet, in his work on Subterranean Normandy, mentions having found sinilar articles either whole or in fiagments, in the Roman necropolis near Dieppe, $\pi$ hich he at first considererl as belonging to the seventecnth century, or perhaps to the time of Henri III. and Henri IV, The Abbé, however, afterwards ehanged his opinion on reading the work of Dr. Collingwoud Bruce, entitled "The Roman Wall," in whieh the author asks the question whether the pipes diseovered at Pierce Bridge, in Northumberland, and in London, at p'aees where Roman stations were known to have existed, belonged to the Romaus? Dr. Wilson, in his Archæology of Scotland, states that tobaeeo was only introdueed as a superior kind of narcotic, and that hemp was already known to the ancients as a sedative. The pipes found in scotland by Dr. Wilson might have served for using this latter substanee. M. Wœehter, in his "Celtic Monuments of Hanover," says that clay pipes from 6 to 8 inches in length had been found in tombs at

* Archseology and Prehistoric Annals of Scotland. p. 681. The Cawdor sculpture and date are described on the authority of Mr. Caruthers, a very trustworthy observer. 
Osnabruck, which proved that the ancients smoked. M. Keferstein, in his "Celtic Antiquities," boldly declares that the Celts smoked. Klemm, in his "History of Christian Europe," states that the smoking of intoxicating plants was known to the Scythians and Africans long before the introduction of tobacco into Europe. Herodotus, in speaking of the Scythians, does not go quite so far, but mentions that the people spread hemp seed on red-hot stones and inhaled the vapour sent forth. It is therefore thought by Baron de Bonstetten that the pipes of which he gives the drawing were used before the introductiou of tobacco into Europe.*

This is by no means the first time that classic authorities have been quoted in proof of the antiquity of smoking. In the Anthologia Hibernica, $\nmid$ for example, a learned treatise aims to prove, on the authority of Herdotus (lib. I. Sec. 36,) Strabo, (lib. vii. 296), Pomponius Mela,(2.) and Solinus (c. 15,) that the northern nations of Europe were acquainted with tobacco, or an herb of similar properties, long before the discovery of America, and that they smoked it through small tubes. Pliny has also been produced to show that Coltsfoot (tussilago farfara, a mucilagenous and bitter herbaceous plant, the leaves of which were once in great faror for their supposed medicinal qualities,) furnished a substitute for the American plant which superseded this and other fancied supplies of the ancients' pipes. Speaking of that plant as a remedy for a cough, (Nat. Hist. xxvi. 16.) Pliny says :- " Hujus aridæ cum radice fumus per arundinem, haustus et devoratus, veterem sanare dicitur tussim; sed in singulos haustus passum gustandum est." This, however, is nothing more than a proof of the antiquity of a process of applying the fumes or steam of certain plants, for medicinal purposes, which is recommended in a treatise on "the Vertues of Colefoct" in the Historie of Plantes, by Rembert Dodoens, translated and published in England in 1578. "The parfume of the dryed leaves" says he, "layde upon quicke coles, taken into the mouth through the pipe of a funnell, or tunnell, helpeth suche as are troubled with the shortness of winde, and fetche their breath thicke or often." So far, how-

* Quoted in the North British Daily Mail, Jnly 24th, 1856, but without naming the original source. It was copied into the Illustrated Times, of July 26th, and by other periodicals, but there also without reference to the original anthority. In this case $\mathbf{I}$ cannot doubt that the writer who thus loosely quotes, or misquotes, the "Archæology of Scotland" does it at second hand, from Dr. Bruce.

+ Vol. I., p. 352 quoted in Notes and Queries, X.48. The subject has been handled in all lights, and each view of the questions it involves has found its defenders in this useful periodical,-doubly useful to those who are cut off from the great public libraries. In $N$. and Q., vol. II., p.154, much curious information is concisely given relative to the assumed use of tobacco, anciently, and in the East. Ibid p. 150. Its Eastern antiquity finds a contradiction on the authority of Lane, and still more of Dr. Meyer of Koniusberg, who discover : $d$ in the works of an old Hindostanee physician, a passage in which tobacco is distinctly stated to have been introduced into India, by the Frank nations, in the year 1609. 
ever, is this ancient process from indicating a mode of inhaling herbs, in any sense equivalent to the American luxury by which it may be supposed to have been superseded, that it is by no means banished, even now, from the practise of ancient female herbalists and domestic mediciners, whom I have known reccmmend the inhalation of the fumes or steam of various plants, not by means of a tobacco pipe, but through the spout of a teapot!

There is no question, however, that many plants have been employed as substitutes for tobacco, since the introduction of the practice of smoking. The slight astringency and diuretic qualities of polytrichum and other Bryacea, led to their use formerly in medicines, and the practice was once common, as I have been assured, in Annandale, and other border districts of Scotland, and is not even now wholly obsolete, of smoking the dried sphagnum latifulium, or the obtusifolium and others of the mosses which abound in the marshy bogs. So also the millefolium or yarrow, one of the various species of the genus Achillea, and several of the herbs which from their shape and the velvet surface of the leaves, are popularly known by the name of mouse ear, have long supplied to the English rustic an economic substitute for tobacco; just as the sloe, hawthorn, sage, and other leaves have furnished a native apology for the tea plant. But the " time immemorial" to which such practice extends probably falls far short of well ascertained dates when tobacco and the tobacco pipe were both recognized as gifts of the new world to the old. But it is curious to note, that one of the most anciently accredited substitutes for tobacco : the coltsfoot, appears to have been employed to adulterate it almost as soon as it came into use in England. Dame Ursla, in Ben Jonson's "Bartholomew Fair," (1614,) thus addresses her dull tapster :- "I can but hold life and soul together with this, and a whiff of tobacco at most, where's my pipe now? not filled, thou errant incubee! · - Look too't sirrah, you were best ; threepence a pipe full, I will ha' made, of all my whole halfpound of tobacco, and a quarter of a-pound of coltsfoot mix't with it too, to itch [eke] it out. I that have dealt so long in the fire will not be to seek in smoke now."

The libraries of Canada furnish very slender means for dallying with the Bibliography of the nicotian art. But some of the references made above may be thought to bear on the subject, and the very terms in which the royal author of the "Counterblaste" assails it as a novelty of such recent origin "as this present age can very well remember both the first author and forms of its introduction," seem 
sufficiently clear evidence that smoking was unknown to Europe before the discovery of this continent. Spain doubtless first enjoyed the novel luxury; probably - at the latest,-not long after the commencement of the sixteenth century. The year 1560 is assigned for its introduction into France, and most commonly that of 1586,in which Admiral Drake's fleet returned from the attack on the west Indian Islands-for its reaching England. But though in all probability only beginning at these dates to attract special attention, the custom of smoking tobacco can scarcely be supposed to have remained unknown to the Spaniards before the close of the fifteenth century, or to have failed to have come under the notice both of French and Englishmen at an early period thereafter. When at length fairly introduced into England, it met with a ready welcome. So early as 1615, we find the popular pott, Joshua Sylvester following in the wake of the royal counterblast, with his:- "tobacco battered, and the pipes shattered about their ears that idly idolize so base and barbarous a weed, or at leastwise overlove so loathsome a vanity, by a volley of holy shot thundered from Mount Helicon," - - tolerable proof of the growing favour for the "weed." The plant itself was speedily brought over and cultivated in various districts, till prohibited by an act of Parliament; and Pepys, in his Diary,-referring to Winchcombe, in Gloucestershire, where tobacco is affirmed to have been first raised in Englaud,-under the date, September 19th, 1667, mentions the information communicated to him by his cozen, Kate Joyce: "now the life-guard, which we thought a little while since was sent down into the country about some insurrection, was sent to Winchcombe, to spoil the tobacco there, which it seems the people there do plant contrary to law, and have always done, and still been under force and danger of having it spoiled, as it hath been oftentimes, and yet they will continue to plant it."*

Another entry of the same indefatigable diarist, furnishes evidence not only of the early faith in the anti-contagious virtues of tobacco, but also of the no less early mode of using it in England according to a fashion which is now more frequently regarded as a special prerogative of young America. On the 7th of June, 1665, Pepys notes that the first sight of the plague-cross, with its accompanying solemn formula of prayer, moved him, not to a devotional ejaculation, as might perhaps seem most fitting, but only to chew tobacco! "The hottest day," he writes, "that ever I felt in my life. This day, much against my will, I did in Drury Lane, see two or three houses marked

* Pepys' Diary, 4th Edition. Vol. III., p. 252. 
with a red cross upon the doors, and 'Lord have niercy upon us!' writ there; which was a sad sight to me, being the first of the kind that, to my remembrance I ever saw. It put me in an ill conception of myself and my smell, so that I was forced to buy some rolltobacco to smell to and chaw, which took away the apprehension."*

The costly nature of the luxury has been assumed as furnishing ample explanation alike of the minute sire of the original tobacco pipe,- which in all probability secured for it in later times its desiguation of "Elfin" or "Fairy Pipe."-and of the early substitution of native pungent and fragrant herbs for the high priced foreign weed. The eircumstances, however, which render the rarer Engli-h lis erature of the sixteenth and seventeenth centuries inaccessible here, have furnished resources of another kind which may perhaps be thought to account for this on other, and no less probable grounds. During a visit to part of the Minnesota Territory, at the head of Lake Superior, in $18 \tilde{5} 5$, it was my good fortune to fall in witl a party of the Saultaux Indians, - as the Cnippeways of the far west are most frequently designated,-and to see them engage in their native dances, in footraces, and other sports, and among the rest: in the luxury of the pipe. It is scarcely necessary to remark that the Indian carries his pipe-stem in his haud, along with his bow, tomahawk, or other weapon, while the pipe itself is kept in the tobacco pouch, generally formed of the skin of some small animal, dressed with the fur, and hung at his belt. But what struck me as most noticeable was that the Indians in smoking, did not exhale the smoke from the mouth, but from the nostrils ; and this, Mr. Paul Kane assures me is the universal custom of the Iudians of the north west, among whom he has travelled from the Red River settlement to the shores of the Pacific. By this means the narcotic effects of the tobacco are greatly increased, in so much so that a single pipe of strong tobacco smoked by an Indian in this manner, will frequently produce complete giddiness and intoxication. The Indians accordingly make use of various herbs to mix with and dilute the tobacco, such as the leaf of the cranberry, and the inner bark of the red willow, to both of which the Indian word kinikinik is generally aplied, and the leaves of the winterberry, which receives the name of pahgezegun. $\dagger$ The cranberry

* Pepy's Diary, 4th Edition. Vol. II., p. 242.

+I am informed by the Rev. Dr. O'Meara, the translator of the Bible in the Chippeway tongue, that the literal significance of kinikinik is "he mixes." kinikangun is "a mixture," and the words are applied by the Indians not to the diluent alone, but to the tohacco and diluents when mixed and prepared for use. So also pahgezegun is "anything mixed," and may be rendered: something to mix with tobaeco. 
and winterberry leaves are prepared by passing them through the top of the flame, or more leisurely drying them over the fire, without allowing them to burn. Among the Creeks, the Chocktaws, and other Indians in the south, the leaves of the sumach, prepared in a similar manner, answer the like purpose. The leaf of the winterberry, or tea berry, (coltheria procumlens, ) has a pleasant aroma, which may have had some influence on its selection. The Indians of the north west ascribe to it the further property of giving them wind, and enabling them to hold out longer in running; but the main object of all such additions appears to be to dilute the tovacco, and thereby admit of its prolonged enjoyment. Having both chewed and smoked the winterberry leaf prepared by the Indians, I am able to speak positively as to the absence of any narcotic qualities, and I presume that with it and all the other additions to the tobacco, the main object is to provide a diluent. so as to moderate the effects, and prolong the enjoyment of the luxury. The same mode is employed with ardent spirits. Mr. Kane remarks of the Chinook Indians: it is a matter of astonishment how very small a quantity of whisky suffices to intoxicate them, although they always dilute it largely in order to prolong the pleasure they derive from drinking.

'I'he custom of increasing the action of the tobacco fumes on the nervous system, by expelling them through the nostrils, though now chiefly confined to the Indians of this continent, appears to have been universally practised when the smoking of tobacco was intronuced into the old world. It has been perpetuated in Europe by those who had the earliest opportunities of acquiring the native custom. The Spaniard still expels the smoke through his nostrils, though using a light tobacco, and in such moderation as to render the influence of the narcotic sufficiently innocuous. The Greek sailors in the Levant very frequently retain the same practice, and with less moderation in its use. Melville also describes the Sandwich Islanders, among whom tobacco is of such recent introduction, as haring adopted the Indian custom, whether from imitation or by a natural savage instinct towards excess ; and evidence is not wanting to prove that such was the original practice of the English smoker. Paul Hentzner, in his "Journey into England." in 1598,* among other novelties describes witnessing at the playhouse, the practice, as then newly borrowed from the Indiaus of Virginia. "Here," he says, "and everywhere else, the English are

* Malone quotes from epigrams and satires of the same date,-eighteen years before the death of Shakespear, - to prove that playgocrs, even at so early a date, were attended by pages, with pipes and tobacco, which they smoked on the stage, where the wits were then wont to sit. Vide Notes and Querics, vol. X., p. 49. 
constantly smoking of tobacco, and in this manner : they have pipes on purpose made of clay, into the further end of which they put the herb, so dry that it may be rubbed into powder, and putting fire to it, they draw the smoke into their mouths, which they puff out again through their nostrils, like funnels, along with it plenty of phlegm, and defluxion of the head."

To this it is, that Justice Overdoo refers in Ben Jonson's " Bartholomew Fair," (Act II, Scene VI.) "Nay, the hole in the nose here, of some tobacco-takers, or the third nostril, if I may so call it, which makes that they can vent the tobacco out, like the ace of clubs, or rather the flower-de-lice, is caused from the tobacco, the mere tobacco!" and so also, in a passage already referred to, in Warner's "Albion's England," the "Indian weed fumes away from nostrils and from throats" of ladies, as well as lords and grooms.

The minute size of the most ancient of the British tobacco pipes which has led to their designation as those of the Elves or Fairies, may therefore be much mrre certainly ascribed to the mode of using the tobacco, which rendered the contents of the smallest of them a sufficient dose, than to any economic habits in those who indulged in the novel luxury. In this opinion I $ı$ m further confirmed by observing the same miniature characteristics mark various specimens of antique native pipes of a peculiar class to which I have already referred as found in Canada, and which appear to be such as, in all probability were in use, and furnished the models of the English clay pipes of the sixteenth century. But if the date thus assigned for the earliest English clay pipes be the true one, it has an important bearing on a much wider question; and as a test of the value to be attached to popular traditions, may suggest the revision of more than one archæological theory based on the trustworthiness of such evidence. A contributor to "Notes and Queries,"* quotes some dogrel lines printed in the "Harleian Miscellany" in 1624, where speaking of the good old times of King Harry the Eighth, smoking is thus ludicrously described as a recent novelty :-

"Nor did that time know

To puff and to blow,

In a pisce of white clay

As you do at this day,

With fier and coale

And a leafe in a hole !"

These lines are ascribed in the original to Skelton, who died in 1529 , and by a.course of reasoning which seems to run somewhat in

*Notes and Queries. Vol. VII., p. 230. 
a circle, it is assumed that they cannot be his, because tobacco was not introduced into England "till 1565 or thereabouts." Brand in his "Popular Antiquities," ascribes its introduction to Drake in 1586 ; while the old keep at Cawdor, already referred to, with its sculptured reynard and his pipe, would carry it back to 1510 , and by implication still nearer the fifteenth century. So peculiar a custom as smoking, would no doubt, at first be chiefly confined to such as had acquired a taste for it in the countries from whence it was borrowed, and until its more general diffusion had created a demand for tobacco, as well as for the pipe required for its use, the smoker who had not acquired an Indian pipe along with the "Indian weed," would have to depend on chance, or his own ingenuity, for the materials requisite for its enjoyment. Hence an old diarist writing about 1680, tells us of the tobacco smokers:- "They first bad silver pipes, but the ordinary sort made use of a walnut shell and a straw. I have heard my grandfather say that one pipe was handed from man to man round the table. Within these thirty-five years 'twas scandalous for a divine to take tobacco. It was then sold for its weight in silver. I have heard some of our old yeomen neighbours say, that when they went to market they culled out their biggest shillings to lay in the scales against the tobacco; now the customs of it are the greatest his majestie hath." In the interval between the primitive walnut-shell pipe, or the single clay pipe for a whole company to partake of the costly luxury, and this later era of its abundant use, the supply of pipes had, no doubt, kept pace with that of the tobacco, and they had undergone such alterations in form as were requisite to adapt them to its later mode of use. Their material also had become su uniform, and so well recognised, that a clay pipe appears to have been regarded, in the seventeenth century as the sole implement applicable to the smoker's art. An old string of rhymed interogatories, printed in Wit's Recreations, a rare miscellany of 1640 , thus quaintly sets forth this idea:-

"If all the world were sand,

Oh, then what should we lack'();

If as they say there were no clay,

How should we take tobacco?"

Towards the latter end of the sixteenth, and in the early years of the seventeenth century, under any view of the case, small clay pipes, such as Teniers and Ostade put into the mouths of their Boors, must have been in common use throughout the British Islands. They have been dredged in numbers from the bed of the Thames, found in 
abundance on various sites in England and Ireland, where the soldiers of the parliament and revolution encamped; and in Scotland in divers localities from the border, northward. even to the Orkneys. They have been repeatedly met with in old Churchyards, and turned up in places of public resort. Occasionally too, to the bewilderment of the antiquary, they are discovered in strange propinquity to primitive, Roman, and medieval relics,- but in a sufficient number of cases with such potters' stamps on them as suffice to assign these also to the sixteenth and serenteenth centuries. At a date so comparatively recent as that of the revolution of 1688 , they must have been nearly as familiar throughout Britain and Ireland, as the larger clay pipe of the present day : and yet towards the end of the eighteenth century we find them described in Scottish statistical reports as "Elfin pipes ;" and when at a later date, they attract a wider attention, it is found that, in total independence of each other, the peasantry of England, sicotland, and Ireland, have concurred in ascribing these modern antiques to the Danes, the Elves and the Fairies! I must confess that the full consideration of all the bearings of this disclosure of the sources of modern popular belief has greatly modified the faith $I$ once attached to such forms of tradition as memorials of the past. The same people who, by means of Welsh triads, genealogical poems, like the Duan Albannach and Eireannach, and historical traditions, like the memory of the elder home of the Saxons in the Gleeman's song, could transmit, by oral tradition alone, the chronicles of many generations, now depend so entirely on the chroniclings of the printing press, that they cannot be trusted with the most familiar traditions of a single century. This no doubt only applies to very modern centuries; but the treacherousness of the historical memory of a rude savage people is sufficiently illustrated be the fact that we search in vain among the Indians of this continent for any tradition of the first intrusion of the white man.

A few general remarks on the varying characteristics of the pipes anciently constructed, or now in use among the Indian tribes of North America will not be out of place here, as a means of illustrating the customs and ideas associated at various times, and among different tribes, with the peculiar rites and usages of the pipe as the special characteristic of the new world. For some of the facts relating to the Indians of the north west, I am indebted to the Rev. Dr. O'Meara, missionary among the Chippeways ; to Dr. George Beattie, formerly United States Indian Agent of the Winnebagos, -who have since been driven to desert their old hunting grounds in 
Wisconsin for the far west, and from their rapidly dimisishing numbers, cannot long survive as a distinct tribe,-and also, in special reference to those of the remote north west, and on the shores of the Pacific, to Mr. Paul Kane, along with the information derived from inspecting a fine collection of Indian relics secured by him during three years travel in the Hudson Bay Company's Territory, and among the neighbouring tribes within the territories of the United States. A comparison of the facts thus obtained with some of the conclusions arrived at by others from the examination of the older traces of the custom and usages of smoking, appear calculated to throw some additional light on the latter, and especially to modify the opinion derived from the investigation of examples of the ancient arts of the Mound Builders, and other aboriginal traces of this continent.

Insignificant, and even puerile, as the subject of the tobacco pipe appears, it assumes an importance in many respects only second to that of the osteological remains of the ancient races of this continent when viewed as part of the materials of its urwritten history. In Messrs. Squier and Davis' valuable "Contribution to Knowledge"* the tobacco pipes found in the ancient sepulchral mounds of the Mississippi Valley are specially noted as constituting not only a numerous, but a highly interesting class of remains, on the construction of which the artistic skill of their makers seems to have been lavished with a degree of care and ingenuity bestowed on no other works. "They are sculptured into singular devices: figures of the human head, and of various beasts, birds, aud reptiles. These figures are all executed in miniature, but with great fidelity to nature." Thus, for example, the authors remark in reference to one pipe-head (Fig. 183, p. 268,) carved in the shape of a toad: the knotted, corrugated skin is well represented, and the sculpture is so very truthful that if placed in the grass before an unsuspecting observer, it would probably be mistaken for the natural object; and they further add: " those who deem expression in sculpture the grand essential, will find something to amuse as well as to admire, in the lugubrious expression of the mouths of these specimens of the toad." The same writers again remark, in describing the immense deposit of pipes found on the "altar" of one of the great mounds in the Scioto Valley, some of them calcined, and all more or less aflected by the fires of the ancient ceremonial of cremation or sacrifice :- "The bowls of most of the pipes are carved in miniature figures of animals,

*Ancient Monuments of the Mississippi Valley, pages 228, 229. 
birds, reptiles, \&c. Not only are the features of the various objects represented faithfully, but their peculiarities and habits are in some degree exhibited. The otter is shewn in a characteristic attitude, holding a fish in his mouth; the heron also holds a fish; and the hawk grasps a small bird in its talons, which it tears with its beak. The panther, the bear, the wolf, the beaver, the otter, the squirrel, the racoon, the hawk, the heron, crow, swallow, buzzard, the paroquet, toucan, and other indigenous and southern birds; the turtle, the frog, toad, rattlesnake, etc., are recognised at first glance."* To this comprehensive list Mr. Squier makes further additions in a work of later date. Contrasting the truthfulness of the carvings from the mounds with the monstrosities or caricatures of nature usually produced by the savage sculptor, he remarks: "they display not only the general form and features of the objects sought to be represented, but to a surprising degree their characteristic expression and attitude. In some instances their very habits are indicated. Hardly a beast, bird, or reptile, indigenous to the country is omitted from the list ;" and in addition to those named above, he specifies the elk, the opossum, the owl, vulture, raven, duck, and goose, and also the alligator. $\uparrow$ Of no less interest are the numerous examples of sculptured human heads, some of them presenting striking traits of individual portraiture, and which are assumed, from the minute accuracy of many of the accompanying sculptures of animals, to furnish faithful representations of the predominant physical features of the ancient people by whom they were made.

Compared with the monuments of Central and Southern America, the sculplured façades of the temples and palaces of Mexico and Peru, the friezes adorned with hieroglyphics, the kalendars, and colossal statues of gods and heroes, of Yucatan: the art which found its highest object in the decoration of a pipe-bowl is apt to appear insignificant enough. Nevertheless, the simplicity, variety, and expression of these miniature works of art, their evidence of great imitative skill, as well as of delicacy of execution, all render them just objects of interest and careful study. But high as is the value which attaches to them as examples of the primitive æsthetic arts of this continent, they have a still higher significance in relation to ethnological inquiries. By the fidelity of their representations of so great a variety of objects derived frum the animal kingdom, they furnish evidence of a knowledge, possessed by these ancient artists of the

* Ancient Monuments of the Mississippi Valley. Page 152.

Antiquities of the State of New York. Page 338. 
Mississippi Valley, of the fauna peculiar not only to southern, but to tropical latitudes, suggestive either of arts derived from a foreign source, and of an intimate intercourse maintained with the central regions where the civilization of ancient America attained its highest devellopment, or else indicative of a migration from the south, and an intrusion into the rorthern area of the continent, of the race of the ancient graves of Central America, bringing with them into their new area the arts of the tropics, and models derived from the animals familiar to their fathers in the parent-land of the race.

That such a migration,- rather than a contemporaneous existence of the same race orer the whole area thus indicated, and maintaining intimate intercommunication and commercial intercourse, is the more probable inference, is suggested on various grounds. If the Mound Builders had some of the arts and models, not only of Central America, but of Peru, they had also the native copper of Lake Superior, and mica believed to be traceable to the Alleghanies, while the gigantic tropical shells of the Gulf of Mexico have been found alike in these ancient mounds and in the graves along the shores of Lake Huron and Georgian Bay. 'The fact indeed that among the specimens of their most elaborate carring, some of the objects represent birds and quadrupeds belonging to latitudes so far to the south, naturally tends to suggest the idea of a central region where the arts were cultivated to an extent unknown in the Mississippi regions, and that those objects manufactured in the localities where such models are furnished by the native fauna, remain only as the evidences of ancient commercial relations maintained between these latitudes and the localities where now alone such are known to abound. But in opposition to this, full value must be given to the fact that neither the relics, nor the customs which they indicate, appear to pertain exclusively to southern latitudes, nor are such found to predominate among the singular evidences of ancient and more matured civilization either in Central or Southern America, while the varied nature of the materials employed in the arts of the Mound Builders, indicate a very wide range of relations; though it cannot be assumed that these were maintained in every case by direct intercourse.

The earlier students of American Archæology, like the older Celtic Antiquaries of Britain; gave full scope to a system of theorising which built up comprehensive ethnological schemes on the rery smallest premises; but in the more judicious caution of later writers there is a tendency to run to the opposite extreme. Dr. Schoolcraft 
certainly manifests a disposition to underrate the artistic skill unmistakably discernable in some of the works of the Mound Builders ; while Mr. Haven solves the difficulty by referring such evidences of art to an undetermined foreign source. After describing the weapons, pottery, and personal ornaments obtained from the mounds, the latter writer adds, "and, with these were found sculptured figures of animals and the human head, in the form of pipes, wrought with great delicacy and spirit from some of the hardest stones. The last-named are relies that imply a very considerable degree of art, and if beliered to be the work of the people with whose remains they are found, would tend greatly to increase the wonder that the art of sculpture among them was not manifested in other objects and places. The fact that nearly all the finer specimens of workmanship represent birds or land and marine animals belonging to a different latitude, while the pearls, the knives of obsidian, the marine shells, and the copper, equally testify to a distant, though not extra-continental origin, may however exclude these from being received as proofs of local industry and skill." ${ }^{* *}$ A reconsideration of the list already given of animals sculptured by the ancient pipe-makers of the mounds, as quoted from the narrative of Messrs. Squier and Davis, along with the later additions of the former, set forth in a form still less in accorlance with such deductions, will, I conceive, satisfy the inquirer that it is quite an over statement of the case to say that nearly all represent animals belonging to a different latitude. The real interest, and difficulty of the question lies in the fact of discovering, alung with so many spirited sculptures of animals pertaining to the locality, others represented with equal spirit and fidelity, though belonging to different latiturles. On this subject, familiarity with early British antiquities indures me to regard such an assignment of all the sculptures of the mounds to a foreign origin, on account of their models being in part derived from distant latitudes, as a needless assumption which only shifts without lessening the difficulty. On the sculptured standing stones of scotland-belonging apparently to the closing era of paganism, and the first introduction of christianity there, - may be seen the elephant, the camel, the tiger or leopard, the ape, the serpent, and other representations or symbols, borrowed, not like the models of the Mound Builders, from a locality so near as readily to admit of the theory of direct commercial intercourse, but some of them from the remote extreme of Asia. The only difference between the imitations of the foreign

\footnotetext{
* Haven's Archæology of the United States. Page 122.
} 
fauna of the Scottish and the ancient American monuments, is that the former occasionally betray, as might be expected, the conventional characteristics of a traditional type,* while the latter, if they furnish evidence of migration, prove it to have been recent, and to a locality not so distant as to preclude all renewal of intercourse with their ancestral birth-land. $†$ Notwithstanding the great spirit displayed in many of the miniature sculptures of the Mound Builders, however, the difference in point of fidelity of imitation between them and the carvings of foreign subjects on the Scottish standing stones though unmistakeable, is not so great as the descriptions of American Archæologists would suggest; while both are alike accompanied by the representations of monstrosities or ideal creations of the fancy, which abundantly prove that the ancient sculptors could work without a model. Some of the liuman heads of the American sculptures for example. if regarded as portraits, must be supposed to be designed in the style of Punch!++ and several of the animals figured in "The Ancient Mcnuments of the Mississippi Valley," e. g. the wild cat, Fig. 159 ; the "very spirited, though not minutely accurate head of the Elk," Fig. 161, and the supposed "cherry birds," Figs. 174, 175, of one of which it is remarked: "nothing can exceed the lifelike expression of the original," fall far short of the fidelity of imitation ascribed to them in the accompanying text.

It has been noted by more than one American Archæologist as a singular fact that no relics obviously designed as idols, or objects of worship, have been dug up in the mound; or found in such circumstances as to cunnect them with the religious practices of the Mound Builders. But the very remarkable characteristics of their elaborately sculptured pipes, and the obviously important part they appear to have played in the services accompanying the rites of sacrifice or cremation, and the final construction of the gigantic earth-pyramids

* It is worthy of note that the objects least truthfully represented among the sculptures of the Mound Builders, also, in some cases at least, appear to be those of animals foreign to the region, e. g. the Toncan (?) "Ancient Monmments of the Mississippi Valley;" Fig. 169, page 260 ; which might have been better described as a Raven; and Fig. 178, also a Toucan, but much inore of a traditional than truthful portraiture.

+ Vide Archæology and Prehistoric Annals of Scotland. Page 501, and Dr. Wise's Notes on Buddhist Opinions and Monuments. Transactions of R.S.E. Vol. XXI. Page 255.

‡Vide Davis and Squier's Ancient Monuments. Fig. 145, described as the most beautiful of the series, and a head, the workmanship of which is unsurpassed by any specimen of ancient American Art, not excepting the best productions of Mexico and Peru,fully bears out these remarks. But in contrast with it may be placed Figs. 143, 146 and 148 ; and as a still stronger illustration of how far the enthusiasm of the most careful observers may lead them compare Fig. 75, page 193, with the description which says of it: "the attitude is alike natural and spirited !" 
which have given the name to the race that furnished the artists by whom they were wrought, all tend to suggest very different associations with the pipe of those ancient centuries from such as now pertain to its familiar descendant. It has accordingly been supposed that the elaborate einployment of the imitative arts on the pipeheads found deposited in the mounds, indicate their having played an important part in the religious solemnities of the ancient race, among whom the number of such relics proves that the practice of smoking was no less universal than among the modern Indians. The conjecture that this practice was more or less interwoven with the primitive civil and religious observances of America is thus illustrated by the authors already quoted, * from the more modern customs and ideas connected with it: "the use of tobacco was known to nearly all the American nations, and the pipe was their grand diplomatist. In making war and in concluding peace it performed an important part. Their deliberations, domestic as well as public, were conducted under its influences, and no treaty was ever made unsignalized by the passage of the calumet. The transfer of the pipe from the lips of one individual to those of another was the token of amity and friendship, a gage of honor with the chivalry of the forest which was seldom violated. In their religious ceremonies, it was also introduced with various degrees af solemnity. The custom extended to Mexico, where, however, it does not seem to have been invested with any of those singular conventionalities observed in the higher latitudes. It prevailed in South America and the Caribbean Islands."

Amid the endless variety which characterises the form of the ancient Mound Builders' pipes, one general type is traceable through the whole. "They are always carved from a single piece, and consist of a flat curved base, of variable length and width, with the bowl rising from the centre of the convex side, From one of the ends, and communicatiug with the hollow of the bowl, is drilled a small hole, which answer the purpose of a tube; the corresponding opposite division being left for the manifest purpose of holding the implement to the mouth." The authors of the "Ancient Monuments of the Mississippi Valley," express their conviction, derived from the inspection of hundreds of specimens which have come under their notice, during their explorations of the ancient mounds, that the instrument is complete as found, and was used without any such tube as is almost invariably employed by the modern Indian, and

*Ancient Monuments of the Mississippi Valley. Yage 229. 
also by the modern perfume-loving oriental when he fills his chibouk with the odorous shiraz or mild latakia. The modern pipe-head of each has a large aperture for the insertion of the tube, whereas in the aucient examples referred to, the perforation is about one sixth of an inch in diameter, and the mouth-piece flattened, and adapted to the lips, so that we can scarcely doubt the mouth was applied directly to the implement, without the addition of any tube of wood or metal. It is otherwise with examples of pipe-heads carved out of the beautiful red pipe stone, the most favourite material for the pipe sculpture of the modern Indian. It would seem, therefore, that the pipe-tube is one of the characteristics of the modern race; if not distinctive of the northern tribes, from the Toltecan and other essentially diverse ancient people of Central and Southern America.

The use of tobacco, from the earliest eras of which we can recover a glimpse, pertained to both; but the pipe-head would appear to be the emblem of the one, while the pipe-stem gives character to the singular rites and superstitions of the other. The incremated pipe-heads of the ancient mound builders illustrate the sacred usages. of the one; while the skill with which the Indian medicine-man decorates the stem of his medicine-pipe, and the awe and reverence with which-as will be presently shown, - the whole tribe regard it, abundantly prove the virtues ascribed to that implement of the Indian medicine man's sacred art. May it not be, that in the sacred associations connected with the pipe by the Mound Builders of the Mississippi Valley, we have the indications of contact between the migrating race of Southern and Central America, among whom no superstitious pipe usages are traceable, and the tribes of the north where such superstitions are most intimately interwoven with all their sacred mysteries?

In one, though only in one respect, a singular class of clay pipes, which have come under my notice, agree with the ancient examples, and would seem thereby still further to narrow the area, or the era of the pipe-stem. During the summer of 1855 , I made an excursion in company with the Rev. George Bell, to some parts of County Norfolk, Canada West, within a few miles of Lake Erie, for the purpose of exploring certain traces of the former natives of the locality. We found at various places along the margins of the smaller streams, and on the sloping banks of the creeks, spots where our excavations were rewarded by discovering relics of the rude arts of the Aborigines. 
These included awls or bodkins, and large needles, made of bone,* sereral stone implements, and a considerable quantity of pottery. The specimens of rude native fictile ware considerably interested me, on account of the close resemblance they frequently bore, not only in material, but in ornamentation, to the ancient pottery of the British barrows.

The potters' art appears to have been practised to a great extent, and with considerable skill, by the ancient races of this continent; nor was it unknown to the Red Indians at the period when their arts and customs were first brought under the notice of Europeans. Adair says of the Choctaws and Natchez, that "they made a prodigious number of vessels of pottery, of such variety of forms as would be tedious to describe, and impossible to name ;" and DeSoto describes the fine earthware of the latter tribe, in the seventeenth century, as of considerable variety of composition and much elegance of shape, so as to appear to him little inferior to that of Portugal. The specimens found by me in County Norfolk, and elsewhere in Canada, are heary and coarse, both in material and workmanship, and neither these nor the objects now to be described, admit of any com: parison, in relation to artistic design or workmanship, with those relics of the Mound Builder's arts, or the more recent productions of Indian skill which suggest a resemblance to them.

Accompanying the rude fictile ware, spoken of, were also discovered several pipe-heads, made of burnt clay, and in some examples ornamented, like the pottery, with rude cherron patterns, and lines of dot-work, impressed on the material while soft. But what particularly struck me in these, and also in others of the same type, including several specimens found under the root of a large tree, at the Mohawk reserve on the Grand River, and presented to me by the Indian (hief and Missionary, the late Peter Jones, (Kahkerraquonaby,) was the extreme smallness of the bowls, internally, and the obvious completeness of most of such examples as were perfect, without any separate stem or mouth piece; while if others received any addition, it must have been a small quill, or stram. They at once recalled to my mind the diminutive Scottish. "Elfin Pipes," and on comparing them with some of these in my possesion, I find that in the smallest of the Indian pipes the capacity of the bowl is even less

\footnotetext{
* Implements of bone, precisely corresponding to some of these, are figured and described by Messrs. Squier and Davis, (page 220,) among the disclosures of the ancient mounds. Such implements, however, have pertained to the rude arts of primitive races in all ages, and where found with other samples of the same pottery in the States, have been supposed to be the implements for working the ornamental patterns on the soft clay.
} 
than the least of those which, from their miniature proportions have been long popularly assigned to the use of the Scottish Elves. Both the pipes and the accompanying pottery totally differ, as Mr. Kane assures me, from any of the manufactures which have come under his notice among the tribes of the North West, with whom, indeed, the potter's art appears to be wholly unknown.

The pottery thus found along with these diminutive Indian clay pipes, is obviously therefore a relic of former centuries, though exhibiting no such evidence as would necessarily suggest a remote antiquity. Similar examples found to the south of the Great Lakes, are thus described by Mr. Squier, in his Aboriginal Monuments of the State of New York: "Upon the site of erery Indian town, as also within all the ancient enclosures, fragments of pottery occur in great abundance. It is rare, however, that any entire vessels are recovered. Those which have been found, are for the most part gourdshaped, with round bottoms, and having little protuberances near the rim, or oftener a deep groove, whereby they could be suspended. A few cases bave been known in which this form was modified, and the bottoms made sufficiently flat to sustain the vessel in an upright position. Fragments found in Jefferson County seem to indicate that occasionally the vessels were inoulded in forms nearly square, but with rounded angles. The usual size was from one to four quarts ; but some must have contained not less than twelve or fourteen quarts. In general there was no attempt at ornament; but sometimes the exteriors of the pots and vases were elaborately, if not tastefully ornamented with dots and lines, which seem to have been formed in a very rude manner with a pointed stick or sharpened bone. Bones which appear to have been adapted to this purpose are often found. After the commencement of European intercourse, kettles and vessels of iron, copper, brass, and tin, quickly superseded the productions of the primitive potter, whose art at once fell into disuse."**

In an able summary of the "Archæology of the United States," embodying a resumé of all that has been previously done, Mr. Samuel F. Haven remarks: "In order tu estimate correctly the degree of skill in handicrafts possessed by the people who were found in occupation of the soil, we must go back to a time antecedent to the decline in all domestic arts which resulted immediately from intercourse with the whites. So soon as more effectire implements, more serviceable and durable utensils, and finer ornaments, could be ob-

\footnotetext{
* Aboriginal Monuments of the State of New York. Page 75.
} 
tained in exchange for the products of the chase, their own laborious and imperfect manufactures were abandoned.*" But just as this reasoning must unquestionably prore in many cases, it fails of application in relation to the absence of the potter's art among the Indians of the North West, for the substitutes found for it are of native manufacture, and present a much greater dissimilarity to the products of European art. Among the Chinooks, for example, inhabiting the tract of country at the mouth of the Columbia River, the only domestic utensils remarked by Mr. Paul Kane, as creditable to their decorative skill were carred bowls and spoons of horn, and baskets and cooking vessels made of roots and grass, woven so closely as to serve all purposes of a pitcher in holding and carrying water. In these they even boil the salmon which constitute their principal food. This is done by placirg the fish in one of the baskets filled with water, into which they throw red hot stones until the fish is cooked. Mr. Kane observes that he has seen fish dressed as expeditiously by this means, as if boiled in the ordinary way in a kettle over a fire.

Keeping in view the evidence thus obtained, it will probably be accepted as a conjecture not without much probability in its favor, that the rude clay pipes referred to, found along with other Canadian relics, and especially with specimens of fictile ware no longer known to the modern Indian,furnish examples of the tobacco pipe in use in the region of the Great Lakes when the northern parts of this continent first became known to Europeans. The application of the old Indian potter's art to the manufacture of tobacco-pipes is a well established fact. Ancient clay pipes of various types and forms have been discovered and described; and in a "Natural History of Tobaceo" in the Harleian Miscellany, $\uparrow$ it is stated that: "the Virginians were observed to have pipes of clay before even the English came there; and from those barbarians we Europeans have borrowed our mode and fashion of smoking."

Specimens of another class of clay pipes of a larger size, and with a tube of such length as obviously to be designed for use without the addition of a pipe-stem, have also been repeatedly met with, and several from Canadian localities are in my own possession. In the Edinburgh Philosophical Journal, February, 1848, Dr. E. W. Bawtree describes a series of discoveries of sepulchral remains, accompanied with numerous Indian relics, made in the district to the

* Sinithsonian Contributions. Tol. VIII. Page 155.

† Vel. I. Page 535. Quoted in Notes and Queries, vol. VII. Page 230. 
south of the River Severn, between Lake Simcoe and Georgian Bay. These included specimens of the large pymulce, or tropical shells of the Florida Gulf, copper kettles, arrow heads, bracelets and other personal ornaments, of copper, beads of shell and red pipe-stone, and also rarious examples of the larger clay pipes: which no doubt belong to an era subsequent to intercourse with Europeans, as the same discoveries included axe-heads and other relics of iron. Another example of this larger form of clay-pipe figured in Dr. Schoolcraft's "History of the Indian Tribes ;"* was also found within the Canadian frontier, in the peninsula lying between Lakes Huron and Erie. It was discorered in an extensive sepulchral ossuary in the township of Beverly, which contained numerous Indian relics, and among others, specimens both of the pyrula perversa and pyrula spirata. Mr. Paul Kane possesses another pipe of the same class, trumpet shaped at the borl, and unusually well baked, which was dug up in the vicinity of the Sault St. Marie, at the entrance to Lake Snperior; so that this class of relics of the nicotian art, appears to be pecularily characteristic of the Canadian frontier. Some, at least, of these Canadian pipes are of no very remote antiquity, but it is curious to note that in form they bear a nearer resembiance than any figured or described among American antiquilies, to such as are introduced in ancient Mexican paintings ; t nor are examples wanting of a more antique style of art. One specimen figured by Mr. Squier in his "Aboriginal Monuments of the State of New York," is thus described: "It was found within an enclosure in Jefferson County. It is of fine red clay, smoothly moulded, and two serpents rudely imitated, are represented coiling round the bowl. Bushels of fragments of pipes have been found within the same enclosure. Some appear to have been worked in the form of the human head. others in representations of animals, and others still in a variety of regular forms. - . Some pipes of precisely the same material and of identical workmanship with those found in the ancient enclosures, have been discorered in modern Indian graves in Cayuga County. One of these in the form of a bird, and having eyes made of silver inserted in the head, is now in the possession of the author."

Pipes of baked clay of a character more nearly approximating to the sculpture of the mounds, are figured in Messrs. Squier and

*Vol. I. Plate VIII. Figs. 5 and 6.

+ Lord Kingsborough's Mexican Autiquitics. Vol. 1V. Plates 17, 57.

$\ddagger$ Plate 76. Fig. 9 . 
Davis's work. In style of art, however, they are greatly inferior. Of two of these (Figs. 76, 77, page 194,) it is remarked: "They were ploughed up in Virginia at a point nearly opposite the mouth of the Hocking river, where there are abundant traces of an ancient people, in the form of mounds, embankments, \&c. One represents a human head, with a singular bead-dress, closely resembling some of those worn by the idols and sculptures of Mexico. The other represents some animal coiled together, and is executed with a good deal of spirit." The latter remark, however, is scarcely borne out by the accompanying illustration, and it seems by no means improbable that these objects furnish specimens of the Indian arts of Virginia in the time of Raleigh. They certainly present no such marked characteristics as to justify their classification with the ingenious sculptures of the Mound Builders. The same remarks apply to examples procured by Schoolcraft, Squier, and other writers; and among such may be included two clay pipes, one of them found in a mound in Florida, and the other in South Carolina, and both described in the "Ancient Monuments of the Mississippi Valley." * Most of the ancient clay pipes that have been discorered are stated to have the same form; and this, it may be noted, bears so near a resemblance to that of the red clay pipe used in modern Turkey, with the cherry-tree pipe-stem, that it might be supposed to have furnished the model. The bowls of this class of ancient clay pipes are not of the miniature proportions which induce a comparison between those of Canada and the early examples found in Britain; neither do the stone pipe-heads of the Mound Builders, suggest by the size of the bowl, either the self denying economy of the ancient smoker, or his practise of the modern Indian mode of exlaling the fumes of the tobacco, by which so small a quantity suffices to produce the full narcotic effects of the favorite weed. They would rather seem to confirm the indications derived from other sources, of an essential difference between the aucient smoking usages of Central America and of the Mound-Builders, and those which are still maintained in their primeval integrity among the Indians of the North West.

Great variety of form and material distinguishes the pipes of the modern Indians; arising in part from the local facilities they possess for a suitable material from which to construct them; and in part also from the special style of art and decoration which has become the traditional usage of the tribe. The favourite red pipe-stone of the Couteau des Prairies, has been generally sought after, both from

* Smithsonian Contributions. Vol. I. Page 191. Fig. 80. 
its easiness of working and the beauty of its appearance. The region of its celebrated quarries is connected with curious Indian traditions, and the locality appears to have been consecrated for many generations, as a sacred neutral ground whereon parties of rival tribes might freely assemble to supply themselves with the material requisite for their pipe manufacture, as secure fiom danger as when the peace-pipe has been smoked, and the tomahawk buried by the Chiefs of the Iudian nations. A pipe of this favourite and beautiful material, found on the shores of Lake Simcoe, and now in my possession, measures five and three quarter inches in length, and nearly four inches in greatest breadth, yet the capacity of the bowl hollowed in it for the reception of tobacco is even less than in the smallest of the "Elfin Pipes." In contrast to this, a modern Winnebago pipe recently acquired by me, made of the same red pipe stone, inlaid with lead and executed with ingenious skill, has a bowl of large dimensions illustrative of Indian smoking usages modified by the influence of the white man.

From the red pipe stone, as well as from limestone and other harder rocks, the Chippeways, the Winnebagos, and the Siouxs, frequently make a peculiar class of pipes, inlaid with lead $\mathrm{Mr}$ Kane has in his possession an ingeniously carved red stone Sioux pipe, in form of a human figure, lying on the back, with the knees bent up towards the breast, and head thrown forward. The hollowed head forms the bowl of the pipe, while the tube is perforated through the annus; as is the case with another, but much ruder example of pipe sculpture, carved from a light colored sandstone found on the Niami River, Ohio.*

The Chinook and Puget Sourd Indians, who evince little taste in comparison with the tribes surrounding them, in ornamenting their persons or their warlike and domestic implements, commonly use wooden pipes. Sometimes these are elaburately carved, but most frequently they are rudely and hastily made for immediate use; and even among these remote tribes of the flat head Indians, the common clay pipe of the fur trader begins to supersede such native arts.

Among the Assinaboin Indians a material is used in pipe-manufacture altogether peculiar to them. It is a fine marble, much too hard to admit of minute carving, but taking a ligh polish. This is cut into pipes of graceful form, and made so extremely thin, as to be nearly transparent, so that when lighted the glowing tobacco shines through, and presents a singular appearance when in use at night or

* Monuments of the Mississippi Valley. Page 247. Fig. 146. 
in a dark lodge. Another favourite material employed by the Assinaboin Indians is a coarse species of jasper also too hard to admit of elaborate ornamentation. 'This also is cut into rarious simple but tasteful designs, executed chiefly by the slow and laborious process of rubbing it down with other stones. The choice of the material for fashioning the farourite pipe, is by no means invariably guided by the facilities which the location of the tribe affurds. A suitable stone for such a purpose will be picked up and carried hundreds of miles. Mr. Kane informs me that, in coming down the Athabaska River, when drawing near its source in the Rocky Mountains, he observed his Assinaboin guides select the favourite blueish jasper from anong the water worn stones in the bed of the river, to carry home for the purpose of pipe manufacture, although they were then fully five hundred miles from their lodges. Such a traditional adherence to a choice of material peculiar to a remote source, may frequentyy prove of considerable value as a clue to former migrations of the tribe.

Both the Cree and the Winnebago Indians carve pipes in stone, of a form now more frequently met with in the Indian curiosity stores of Canada and the States than any other specimens of native carving. The tube, cut at a sharp right angle with the cylindrical bowl of the pipe, is ornamented with a thin vandyked ridge, gencrally perforated with a row of holes, and standing up somewhat like the dorsal fin of a fish. The Winuebagos also manufacture pipes of the same form, but of a smaller size, in lead, with considerable skill.

Among the Cree Indians a double pipe is occasionally in use, consisting of a bowl carred out of stone without much attempt at ornament, but with perforations on two sides, so that two smokers can insert their pipe-stems at once, and enjoy the same supply of tobacce. It does not appear, however, that any special significance is attached to this singular fancy. The Saultaux Indians, a branch of the great Algonquin nation, also carve their pipes out of a black stone, found in their country, and evince considerable skill in the execution of their elaborate details. In the curious collection of pipes now in the possession of G. W. Allan, Esq., and including those obtained by Mr. Kane among the Indians of the north-west, are two Chippeway pipes carved by the Indians bordering on Lake Superior, out of a dark close-grained stone, easily wrought and admitting of considerable minuteness of detail. One of these, (Plate II. Fig. 2,) mensuring six and a half inches long, consists of a quadrangular tube, from which. rises the bowl in the shape of a human head, of very sphynx-like aspect; and with white beads inserted for the eyes ; 
behind this an Indian seated on the ground holds his hands to each side of the head, (colossal in proportion to him,) in front is another Inrian seated on a chair, and before him stands a third figure neatly carved out of the red pipe stone, while between them is a miniature barrel cut from a white stone found chiefly on St. Joseph's Island. All the figures are well proportioned and carved with consilerable minuteness of detail. Some of the details in this example-the chair and the barrel,-are obviously borrowed from European models, but the general design is purely Indian; the figures are further completed with native head dresses of feathers, and the whole conception and execution well illustrate the usual style of the more elaborate Chippeway pipe sculptures.

One of the most celebrated of these Indian pipe sculptors is Pabahmesad, or the Flier, an old Chippeway still living on the Great Manitouanin Island in Lake Huron; but more generally known as Puahgunelva: the Pipe Maker, literally "he makes pipes." Though brought in contact with the Christian Indians of the Mahnetooahning, or Manitoulin Islands, Dr. O'Meara informs me that he resolutely adheres to the pagan creed and rites of his fathers, and resists all the encroachments of civilization. His materials are the muhkuhdapucingunahbeck, or black pipe-stone of Lake Huron, the wahbepuahgunahbeck, or white pipe-stone, procured on St. Joseph's Island, and the mislopicahgunahbeck, or red pipe-stone of the Couteau de Prairies. His saw, with which the stone is first roughly blocked out, is male by himself out of a bit of iron hoop, and his other tools are correspondingly rude; nevertheless the workmanship of Pabahmesad shows him to be a master of his art. One of the specimens of his skill has been deposited by Dr O'Meara in the museum of 'Trinity College, Dublin, which, from the description I have received, appears to correspond rery closely to the example figured on plate II. Another of the Chippeway black-stone pipes in Mr. Allan's collection is a square tube terminating in a horse's head, turned back, so as to be attached by its nose to the bowl of the pipe, and on the longer side of the tube two figures are seated, one behina the other, on the grousd, with their knees bent up, and looking towards the pipe bowl. A different specimen of the Chieppeway pipe, brought from the nortl-west by Mr. Kaue, is made from the root of a red deer's horn, inlaid with lead, as in the red pipe-stone and limestone pipes alrearly referred to as made by the Chippeways, the Winnebagos, and the Siouxs.

But the most remarkable of all the specimens of pipe sculpture 
executed by the Indians of the north-west, are those carved by the Babeen, or big-lip Indians; so called from the singular deformity they produce by inserting a piece of wood into a slit made in the lower lip. The Babeen Indians are found along the Pacific Coast, about latitude $54^{\circ} 40^{\prime}$, and extend from the borders of the Russian dominions east-ward nearly to Frazer River. Some of the customs of the Babeen Indians are scarcely less singular than that from whence their name is derived; and are deserving of minute comparison with the older practices which pertained to the more civilized regions of the continent. This is especially the case in relation to their rites of sepulture, wherein they make a very marked distinction between the sexes. Their females are wrapped in mats, and placed on an elevated platform, or in a canoe raised on poles, but they invariably burn their male dead.

The pipes of the Babeen, and also of the Clalam Indians occupying the neigubouring Vanconver's Island, are carred with the utmost elaborateness, and in the most singular and grotesque devices, from a soft blue claystone or slate.

Their form is in part determined by the material, which is ouly procurable in thin slabs; so that the sculptures, wrought on both sides, present a sort of double bas-relief. From this, singular and grotesque groups are carved, without any apparent reference to the final destination of the whole as a pipe. The lower side is generally a straight line, and in the specimens I have examined they measure from two or three, to fifteen inches long; so that in these the pipe-stem is included. A small hollow is carved out of some protruding ornament to serve as the bowl of the pipe, and from the further end a perforation is drilled to connect with this. The ouly addition made to it when in nse is the insertion of a quill or straw as a montin piece. One of these shewn on Plate II., Fig. I., is from a drawing made by Mr. Kane, during his residence among the Babeen Indians. The original measured seven inches long. Plate III., is cspied from one of the largest and most elaborate of the specimens bruught back with him; it measures nearly fifteen inches long, and supplies a highly characteristic example of Babeen art.

Messrs. Squier and Davis conclude their remarks on the sculptures of the mounds, by observing: "It is unnecessary to say more than that, as works of art, they are immeasurably beyond anything which the North American Indians are known to produce, even at this day, with all the suggestions of European art, and the adrantages afforded by steel instruments. The Chinooks, and the Indians 


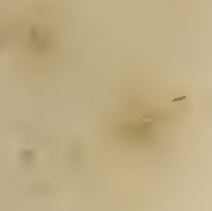




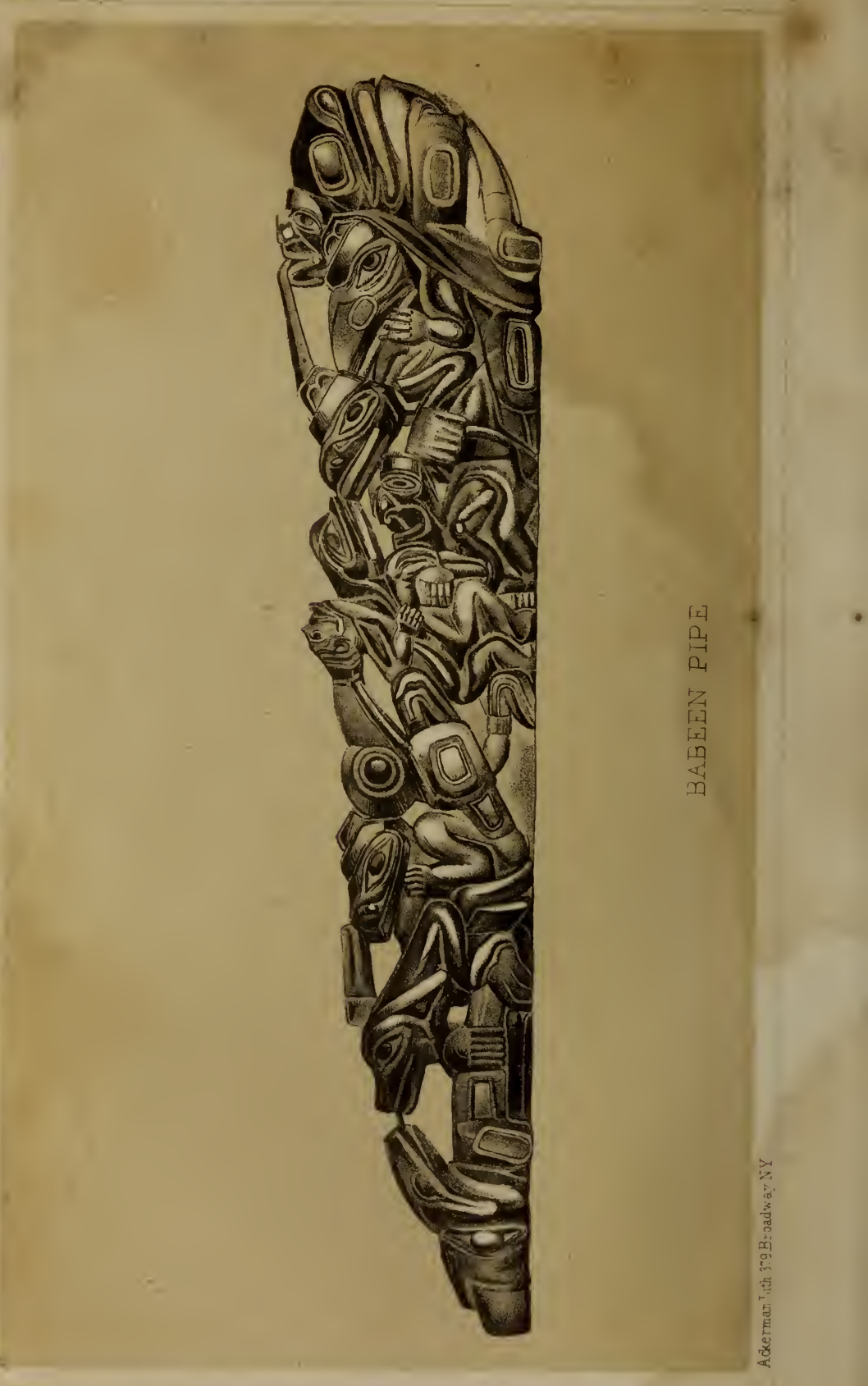




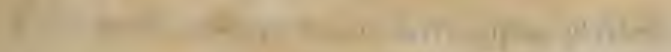

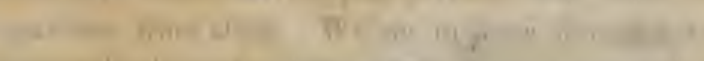

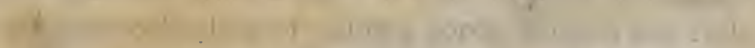

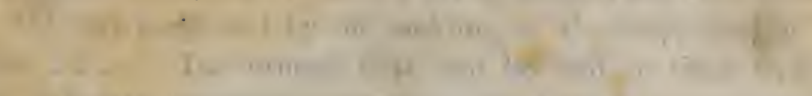

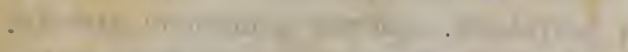

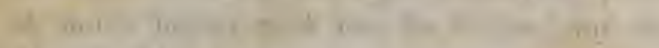

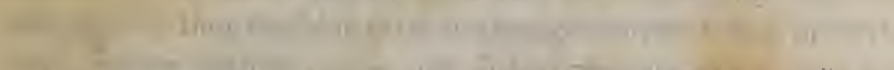

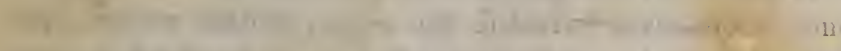

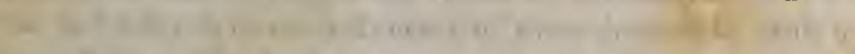

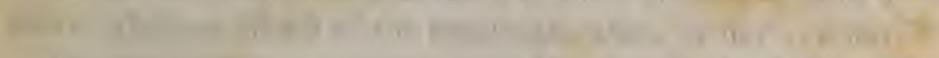

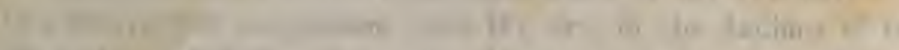

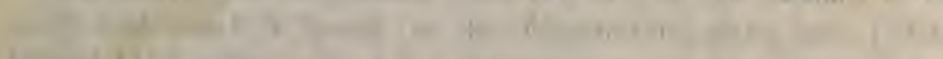
$1+-111$

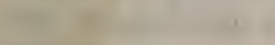

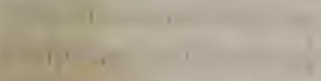

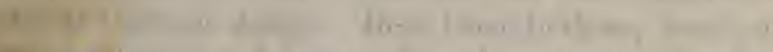

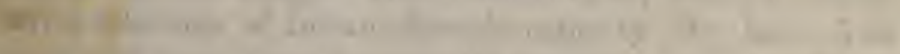

.

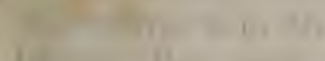

$11+100$

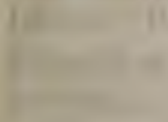



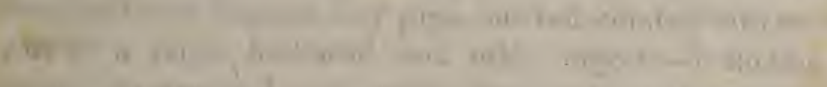

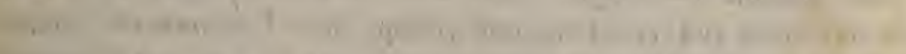

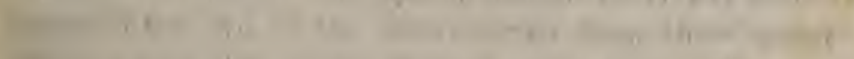

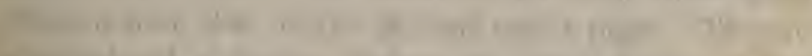

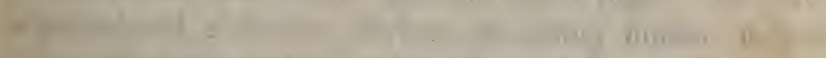

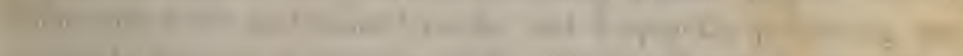

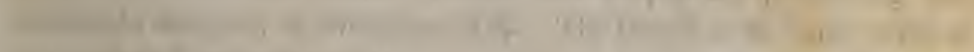

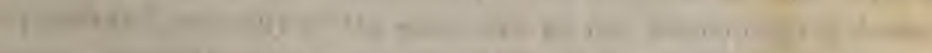

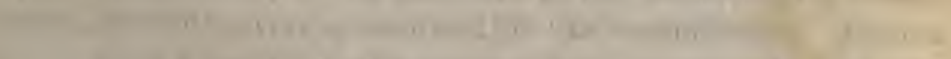

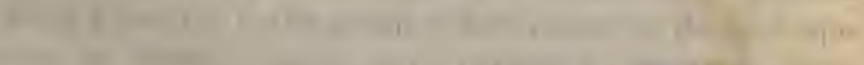

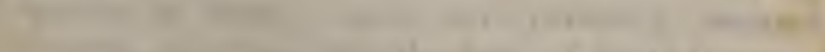

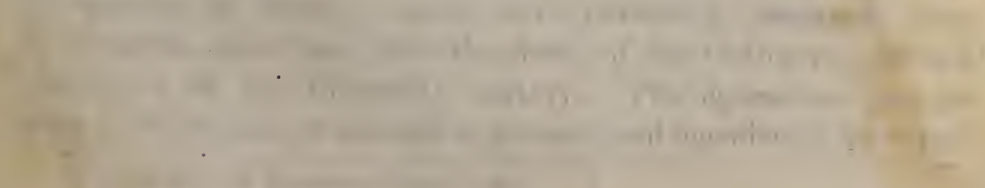



of the north-western coast, carve pipes, platters, and other articles, with much neatness, from slate. We see in their pipes, for instance, a heterogeneous collection of pulleys, cords, barrels, and rude human figures, evidently suggested by the tackling of the ships trading in those seas. . . . . The utmost that can be said of them is, that they are elaborate, unmeaning carvings, displaying some degree of ingennity. A much higher rank ean be claimed for the Noundsculptures; they combine taste in arrangement with skill in workmanship, and are faithful copi-s, not distorted caricatures, from nature. So far as fidelity is concerned, many of them deserve to rank by the side of the best efforts of the artist-naturalists of our own day." **

This descriptive comparison with the arts of the Indians of the north-west coast is based, as the illustrations giren here (Plates II. and III.) suffice to show, on deductions drawn frọn the examination of specimens very different from those which have been brought from the same localities, or investigated in the hands of the native sculptors, and obviously constitute the true illustrations of Indian slill and artistic design. In addition to these, however, among the varied collection of Indian relies brought by $\mathrm{Mr}$. Kane firm the north-west coast, there is one of the ingenious examples of imitative skill referred to by Mr. Squier, which was procured on Tancouver's Island. But while this exhibits evidence of the same skillful dexterity as the other carvings in the blue pipe-slate of the Clalam and Babeen Indians, it presents the most striking contrast to them, alike in design and style of art. It has a regular bowl, imitated from that of a common clay pipe, and is decorated with twisted ropes, part of a ship's bulkhead, and other objects-including even the head of a serew-nail, - all equally familiar to us, but which no doubt attracted the eye of the native artist from their novelty. Very different from this are the genuine native pipes. They are composed of raried and elaborate devices, including human figures, some of them with birds' and beasts' heads, and frequently presenting considerable accuracy of imitatire skill. The frog is a farourite subject, represented generally of the same size as the accompanying human figures, but with a very spirited and life-like verisimilitude. In some of the larger pipes, the enlire group presents much of the grotesque exuberance of fancy, mingled with imitations borrowed direct from nature, which constitute the charm of the Gothic ecclesiastical sculptures of the thirteenth century. The figures are grouped together in the oddest varieties of pusture, and ingeniously interlaced,

* Monuments of the Mississippi Yalley, p. 272. 
and comnected by elaborate ornaments ; the intermediate spaces being perforated, so as to give great lightness of appearance to the whole. But though well calculated to recall the quaint products of the medieval sculptor's chisel, so far are these Babeen carvings from suggesting the slightest resemblance to European models, that when first examining them, as well as specimens in bone and ivory from the same locality,-and still more so, some ivory carvings executed by the Tawatin Indians on Frazer River, - I was struc kwith certain resemblances to the peculiar style of ancient Mexican Art. Such resemblances may be fanciful or accidental. 'To me at least they were suggested by no preconceived theory of Mexican migration, as investigations in another direction have inclined me to adopt ideas even less suggestive of such than those generally set forth by American ethnologists. But while the sculptured Babeen and Clalam pipes cannot be compared to some of the more faithful imitations of objects of nature from the mounds, they furnish very noticeable proofs of initative skill, and are well worthy of consideration as specimens of modern native at, which, if found in the ancient mounds, would have excited no less wonder and admiration than many of the relics figured from among their disclisures.

But there is another conclusion, of more general application, suggested to me by these Babeen sculptures. They are descrving of special consideration, from illustrating, in some respects, the just method of inductive history, as lerircd from ancient relics. Struck with the discrepaney which every careful investigator of the subject must notice between the elaborate art of the finer sculptures, and especially the pipe-heads of the mounds, and any other traces of the skill and civilization of their builders, Mr. Haren assumes a foreign origin for all such sculptures, while others have inferred from them a native civilization in the Mississippi and Ohio Talleys, corresponding in all respects to these isolated examples of art; just as, from a rude but graceful Gieek rave, we can infer the taste of a Callicrates or a Phidias. But it is important to note, that while the Babeen sculptor executes a piece of pipe-carving so elaborate and ingenious as justly to excite our wonder and admiration, it furnishes no test of his general progress in arts or civilization, for, on the contrary, he is ruder and more indifferent to the refinements of dress and decoration th:m many Indian tribes who produce no such special examples of ingenious skill. Some of the conclusions which such facts suggest will, I suspect, be found applicable to not a fow of the 
deductions derived by European archæologists from isolated examples of primitive art.

The pipe, however, which presents so many and characteristic forms, among the Indian tribes of the far west, whatever may have been its importance in ancient times, is no longer the special object of sacred associations. It is to the pipe-stem that the modern Indian attaches that superstitious reneration which among the Mound Builders would appear to have pertained to the pipe itself. The medicine pipe-stem is the palladium of the tribe, on which depends its safety in peace and its success in war, and it is accordingly guarded with all the veneration, and surrounded with the dignity, befitting so sacred an institution; while in its use in the war-council, or in the medicine dance, so long as the proper and consecrated pipe-stem is employed, it matters not whether the pipe itself be of the richest carving of which the red stone of the couteau des prairies is susceptible, or be the begrimed stump of a trader's English "clay."

The medicine pipe-stem carrier is accordingly an office of great dignity in the tribe, and its holder is endowed with special, though somewhat burdensome, honors and privileges. A highly ornamental tent is provided for his use, and frequently he is required to have so many horses as renders the office even more onerous than honourable. A bear-skin robe is set apart for wrapping up the medicine pipe-stem, when carried, and for laying it on while exposed to view. When wrapped up in its covering, the pipe-stem is usually carried by the farourite wife of the dignitary, while he himself bears in his hands-and not unfrequently on his head - the medicine bowl, out of which he takes his food. But though the sacred pipe-stem is almost invariably horne by the wile of the Indian dignitary, it is never allowed to be uncovered in the presence of a woman, and should one even by chance cast her eyes on it when thus exposed, its virtues can only be restored by a tedious ceremony, designed to counteract the evil effects and to propitiate the insulted spirit. If the stem is allowed to fall to the ground, whether designedly or from accident, it is in like manner regarded as an omen of evil, and many elaborate ceremonies bave to be gone through before it is reinstated in its former favour and beneficent influence. Mr. Kane met with a young Cree half-breed who confessed to him that, in a spirit of daring scepticism, he had once secretly thrown down the medicine pipe-stem and kicked it about; but soon after its official carrier was slain, and such misfortunes followed as left no doubt on his mind of the awful 
sacredness pertaining to this guardian and avenger of the honor of the tribe. The sacredness which attaches to the medicine pipe-stem pertains in part also to its bearer. Many special honors are due to him, and it is even a mark of disrespect, and unlucky, to pass between him and the fire.

At Fort Pitt, on the Sascatchewan River, Mr. Kane informs me that he met with Kea-Keke-Sacowaw, the head chief of the Cree nation, then engaged in raising a war party to make war on the Blackfeet. He liad accordingly eleven medicine pipe-stems with him, gathered from the different bands of the tribe who had already enlisted in the cause, and each committed to him by the medicineman of the band. Armed with these sacred credentials, he proceeds through the encampments of his nation, attended by a few of his own immediate followers, but without the pipe-stem bearers, whose rights and privileges pass for the time being to the chief. Whenever he comes to an encampment he cal's on the braves to assemble, tells them he is getting up a war party, recounts to them the unavenged wrongs of the tribe, recalls the names of those slain in former feuds with the Blackfeet, and appeals to them to join him in revenging their death. Throughout such an oration the tears stream down the cheeks of the excited orator, and this is styled "crying for war." On such occasions the medicine pipe-stems are not uncovered, but Mr. Kane having persuaded the Cree Chief to sit for his portrait, he witnessed the cerenony of "opening the medicine pipestem," as it is called, and during its progress had to smoke each of the eleren pipes before he could be allowed to commence his work. His spirited portrait represents the grim old chief, decorated with his war-paint, and holding in his hand the medicine pipe-stem, elaborately adorned with the head and plumes of an eagle.

In the grave ceremony of opening the medicine pipe-stem, the Crees make use of a novel addition to the tobacec. It is procured from the leaves or fibres of a species of cedar or spruce, whicb, when dried and burnt, yields a very pleasing fragrance. A handful of this was thrown on the fire in the middle of the room, and filled it with the fragrant smoke, and some of the same was sprinkled on the top of the tobacco each time one of the medicine pipe-stems was used.

All this ceremonial, and the peculiar sanctity attached to the pipestem, apart from the pipe, are special characteristics of the Red Indian of the North West, of which no trace is apparent in the singular memorials of the ancient Mound Builders, or in the sculp- 
tures and paintings of Mexico. Throughout the whole elaborate illustrations of Lord Kingsborough's great work it is difficult to discover a trace of Mexican usages connected with the tobacco-pipe, and in no one can I discern anything which appears to represent a pipe-stem. In volume IV, plate 17, of a series copied from a Mexican painting preserved at Pass, in Hungary, a figure coloured as a black carries in his hand a plain white pipe, already referred to as some $\pi$ hat of the form of the larger clay pipes found in Canada and in the State of New Tork, and from the bowl rises yellow flames. On plate 57 of the same volume, copied from a Mexican painting in the Borgian Museum, in the College of the Propaganda at Rome, may be seen another figure, holding what seems a small clay tobacco pipe, from whence smoke proceeds. One or two other pictures appear to represent figures putting the green tobacco leaf, or some other leaf, into the pipe, if indeed the instrument held in the hand be not rather a ladle or patera. But any such illustrations are rare, and somewhat uncertain; and it appears to be undoulted that the tobacco pipe was not invested in Central America with any of those singular and sacred attributes which we must beliere to have attached to it among the ancient Mound Builders of the Mississippi Valley; and which under other, and no less peculiar forms, are reverently maintained among the native tribes of the North-West, constituting owe of the most characteristic peculiarities of the American aborigines, and one well deserving of the careful study of the Ethnologist.

Assuming it as a fact, demonstrated by a variety of independent evidence, that the singular practice of smoking narcotics originated among the native tribes of America, and was communicated for the first time to the Old World, after its discovery by Columbus, it becomes a subject well worthy of consideration how rapid and universal was the diffusion of this custom throughout the world. Not only have Europe and Asia, in later times, disputed with America the origin of this luxurious narcotic art; but travellers who return from the mysterious tropical centre of old Africa find there, in like manner, the use of the tobacco pipe, among tribes to whom the sight of the first white man is strange and repulsive. Such facts are worthy of very careful consideration by the Ethnologist. They prove how fallacious is that mode of reasoning, which, in treating of the natural history of man, takes no account of the predominating influences of reason, intellect, and experience, as manifested even among the rudest savages; and seeks to apply the same law to 
man as the lower animals. They serve also to illustrate the indirect means by which the influences of a remote civilization may be extended, and thereby to explain some of the singular coincidences with which the Archæologist is familiar, in the traces of widely diffused primitive arts.

The daring traveller Charles John Andersson, the first explorer of the country of the Damaras, in "his "Lake Ngami," furnishes the following interesting account of the African use of the weed :

"The Hill-Damaras subsist chiefly upon the few wild roots which their sterile neighbourhood produces. Most of them, however, managc to raisc a little tobacco, for which they have a perfect mavia, and which they ralue nearly as much as the neeessaries of life.

"They also cultivate 'dacka,' or hemp, not as with us, for its fibrc, but for the sake of the young leaves and seeds, which they use as a substitute for tobacco, and which is of the most intoxicating and injurious eharaeter. It not unfrequently happens, indeed, that those who indulgc tou freely in the use of this plant are affeeted by disease of the brain.

"The manner in whieh the Hill-Daniaras smoke is widely different from Hindu, Mussulman, or Christian. Instead of simply inhaling the smoke, and then immediately letting it cseape, either by the mouth or nostril, they swallow it deliberately. The process is too singular to bc passed over without notice. A small quantity of water is put into a large horn,- -usually of a Knodoo,-three or four feet long A short clay pipe, filled either with tobacco or dacka, is then introduccd, and fixed vertieally into the sidc, near the cxtremity of the narrow end, commnnieating with the interior by means of a small aperture. This being done, the party present place themselves in a eircle, observing deep silence; and with open mouths, and + yes glistening with delight, they anxiously abidc their turn. The chief man usually has the honor of enjoying the first pull at the pipe. From the moment that the orifice of the horn is applied to his lips he seems to lose all consciousness of everything around him, and becomes entirely absorbed in the enjoyment. As little or no smoke eseapcs from lis mouth, the effeet is soon sufficiently apparent. His features become contorted, lis eye glassy and vacant, his mouth covered with froth, his whole body convulscd, and in a fcw seconds he is prostrate on the ground. A little water is then thrown over his body, proceeding not unfrequently from the mouth of a friend; his hair is violently pulled, or his head uncercmoniously thumped with the hand. Thcse somewhat disagrecable applieations usually have the effeet of restoring him to himself in a few minutes. Cascs, howercr, have been known whcre the pcople have died on the spot, from overcharging their stomachs with the poisonous fumes. The Ovaherero use tobacco in a similar manner, with this difference only, that they inhale the smoke simply through short clay pipes, without using water to cool it, which of course makes it all the more dangcrous."

It would seem, alike from the American and the African modes of using the tobacco or otber narcotics in smoking, and no less so from the Chinese and Malay employment of opium in a similar manner, 
that the primitive use of such among all races has becn attended with gross intemperance. The inference, therefore, is probably not an illegitimate one, which ascribes the small size of the oldest British tobacco pipes, not to the economy or moderation of Elizabethan and Jacobite smokers, but rather to their practising the nicotian art in close imitation of its wild forest originators. This is nowhere more curiously and discriminatingly indicated than in its prescription for the cure of the mental disorder treated of by the quaint author of "The Anatomy of Melancholy," nimself evidently a lover of the weed: "Tobacco, divine, rare, superexcellent tobacco, which goes far beyond all the panaceas, potable gold, and philosopher's stones, a sovereign remedy to all diseases. A good vomit. I confess; a virtuous herb, if it be well qualified, opportunely taken, and medicinally used; but as it is commonly abused by most men, which take it as tinkers do ale, 'tis a plague, a mischief, a violent purger of goods, lands, health; hellish, devilish, and damued tobacco, the ruin and overthrow of body and soul!" Such a deseription of the extent to which tobacco was "commonly abused," in the early part of the seventeenth century (1621) is only explicable by such modes of partaking of it as still prevail among savage tribes, for scarcely even the grossest excesses of the modern smoker and chewer would admit of such terms of denunciation.

The growing size of the tobacco pipe, ass it approaches the era of the Revolution, indicates the introduction of a contemporaneous nicotian revolution also, which adapted the pipe of the Indian medicine-man to the philosophicul reveries of an English Newton; and within a century from 'Zacharie Boyd's association of tobacco with the dissipation of "The wine pint," enabled the devout author of the "Gospel Somnets," to superadd to these his "Smoking Spiritualized: inserted as a proper subject of meditation to smokers of T'obacco; the first part being an Old Meditation upon smoking Tobacco; and the second a new addition to it. or Improvement of it." "* In his "improvement" of his text the grave divine indulges in nicotian similes, such as, from less reverent hands, would seem profane; comparing the "naughty foreign weed" to "the plant of" great renown," to "Jesse's flower" and "Sharon's Rose!" and

* "Gospel Sonnets, or Spiritual Songs, in six parts, conccrning Creation and Redemption, Law and Gospel, Justification and Sanctification, Faitli and Sense, Heaven and Hell. By the late Reverend Mr. Ralph Erskine, Minister of the Gospel at Dunfermline," My copy is the 25th Edition. Edinhurgh, 1797:-a sufficient evidence of the popularity which this work once had. 
"The smoke, like burning incerse," to devout prayer; closiug ench stanza with the refinain :

"Thus think, and smoke 'l'obacco."

In this the finciful moralist "improved" on an old song, which has been traced to the early part of the seventernth century, and is still preserved on more than one Broadside of dates as early at least as 1670 and 1672. In the former of these it bears the initials " $G$. W." supposed to be those of George Wither, who is reputed to have found solace in the iuxury it celebrates. This unlucky puritan poet, who died in 1667, is said by his unloving biographer, Anthony A'Wood, to have ored his life, on one occasion, to a bon-mot of a witty poetic rival, sir John Denham. The royalist-as the author

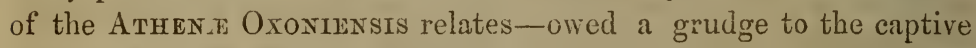
poet, some of his family estates having got into Wither's clutches. Nevertheless, he modestly prayed his Majesty not to hang him, for so long as Wither lived, he (Sir John Denham) would not be accounted the worst poet iu England! Notwithstanding this slur on Wither's poetic repute, the song has evidently enjoyed great and enduring popularity, as is proved by numerous variations, and the gradual modernizing process it has gone through. The version of it which furnishes a text for the Rev. Ralph Erskine, betrays the touches of a modern hand; but in its general form it most nearly resembles the Broadside of 1672 , with the antique flavour of which these "tobacco fumes" may fitly exhale their concluding whiff:

The Indian weed, withered quite,

Green at noon, cut down at night,

Shews tliy decay ;

All flesh is hay,

Thus think, then drink tobaceo.

'The pipe that is so lily white,

Shows thee to be a mortal wight ;

Even as such,

Gone at a touch,

Thus think, then drink tobacco.

And when the smoke ascends on high,

Think thou behold'st the vanity

of worldly stuff,

Gorre at a puff;

Thus think, and drink tobaceo. 
And when the pipe grows foul witlin,

Think on thy soul defiled with sin;

And of the fire

It doth require;

Thus think, then drink tobaeco.

The ashes that are left belind,

May serve to put thee still in mind.

That unto dust

Returil thou must;

Thus think, then drink tobaceo.

Most of the foregoing pages were already thrown off when the Gateshead Observer, of June 6th, 1857, reached me, with the follow. ing notice of proceedings at a meeting of the Society of Antiquaries of Newcastle-on-Tyne. It may very fitly be appended as a note to this sketch, as sufficing to show the latest views of my friend, Dr. Bruce, on the antiquity of pipes and tobacco. It will be seen that he still speaks of the miniature Elfin pipes as medieval; but subsequent remarks seem to indicate that by this term he means the era of Queen Elizabeth, if not indeed that of the Revolution, though neither of them would be generally recognised as pertaining to the province of the medieval historian.

\section{"A PAPER-UF TOBACCO."}

" Dr. Bruce said, when the circular convening the meeting was issued, there was no paper in prospect, and he had therefore written a short one, not anticipating the many interesting commuuications which had filled up the meeting so agrecably. His paper was on the subject of the clay-pipes occasionally found in situations where we should only expect to find remains of a time long anterior to that of Sir Walter Raleigh. To this subject lis attention had been turned, within the last few days, by a letter received by the Treasurer (Mr. Fenwick) from a mutual friend-Dr. Daniel Wilson, of Torouto. The Dector wrote:- 'What says Dr. Bruce to the Roman tobacco-pipes now? Tell him I have got a crow to pluck with him for that. I get quoted from his pages, and held responsible for much more than I ever thought, said, or meaut to say. Let him look-out for a misive from the land of tobaceo.' The passage referred to, in his (Dr. Bruce's) second edition of 'The Roman Wall,' had, curiously enough, and rexatiously enough, been more quoted and translated, perhaps, than auy other. It asked if smoking pipes must be numbered among Romau remains-such pipes, (some of the ordinary size, others of pigmy dimensions, with intermediate sizes,) having been found in Roman stations, in close association with remains of undoubted Ruman origin. Dr. Wilson was quoted on the subject, where, in his Archæology of Scotland, he speaks of "Celtic," "Elfin," or "Danes'" pipes, occasionally found under circumstances raising the supposition that tobaceo was only introduced as a superior substitute for older narcotics Dr. Bruce produced several specimens-onc, a tiny bowl, dug 
from a depth of ten feet, in 1854, at the back of the Assembly Rooms of Netreastle, where, when a sewer under the Viearage House was in course of eonstruction, he was on the look-out for remains of the Roman Wall. In the Antwerp Museum, sureh pipes are exhibited as, Roman antiquities; and some were found near the foundations of the Wall of Roman Loudon, when laid bare in 1853. Still, to Dr. Wilson's 'Transatlantic inquiry: 'What says he to the Roman tobaeco pipes now ?' he had to reply, that he feared they were but medieval, and, moreover, of a late date. He would briefly state the grounds of this eonclusion : -1 . They were only met with, here and there, in eonnection with Roman remains; while in every Roman station, all the kinds of pottery used by the Romans were invariably found.-2. No traces of the practice of smoking presented themselves in elassie authors.-3. Ancient herbals eontained no notice of any vegetable used for smoking with pipes.-4. These old pipes, laid together, exhibited a regular gradation in size, from the fairy bowl to the pipe of the present day.-5. Elfin pipes were found some few years ago at Hoylake, in Cheshire, on the site where the troops of William III. were encamped previous to their embarkation for Ireland; on the battle-field of Boyne at Ihundalk; and in other parts of Ireland where William's troops were quariered.- ' With respect,' said one of his (Dr. Bruce's) reviewers, 'to the little tobacco pipe bowls, we may observe that their eomparatively diminutive size may be well explained by the fact that, in the time of Queen Elizabeth tobacco was sold at five guineas the ounce, and that, in aftertimes, those who indulged in the expensive luxury of smoking tobucco, were aceustomed, in buying it, to throw five shilling piees into the opposite scale.' He (Dr. Bruee) feared, then, that the Elfin pipes-the Fairy pipes-the Danes' pipes-must be placed in the same eategory with- 'Severus' Wall!"

"At the conclusion of the paper, Mr. E. Spour stated that he had seen turned up, in building operations, hundreds of pipes together, smallel than any of those on the table, near the town walls of Newenstle."

From this it appears that the learued author of "Tre Romar W $\Delta \mathrm{ur}$, , no longer accords to his mural Legionary the luxury of a pipe; and the defence of this venerable classic institution must be resigned to the more chivalrous archrologists of the Continent, and especially to the Antiquaries of Antwerp, where Elfin tobacco-pipes are still exhibited as Roman relics; and among whom, we trust, still survives some collateral descendant of the renerable and praiseworthy Aldobrand Oldenbuck, the happy progenitor of the Laird of Monkbarns !

\footnotetext{
FIFTY COPIES PRINTED AT TIIE PRESS OF

LOVELL AND GIBSON, PRINTERS, YONGE STREET, TORONTO.

1857.
} 